\title{
La construcción del Estado en España: haciendo historia cultural de lo político ${ }^{1}$
}

DOI

http://dx.doi.org/10.1590/2236-463320161301

\section{Juan Pro Ruiz}

Universidade Autónoma de Madrid, Madrid, Espanha

1

Este artículo ha sido realizado en el marco del proyecto HAR2012-32713 del Plan Nacional de I+D+i de España.

2

Un ejemplo reciente podría ser el libro de ORDUÑA REBOLLO, Enrique. Historia del Estado español. Madrid: Marcial Pons Historia - Fundación Alfonso Martín Escudero, 2015.

3

TILLY, Charles (ed.). The Formation of National States in Western Europe. Princeton: Princeton University Press, 1975. EVANS Peter B.; RUESCHEMEYER, Dietrich; SKOCPOL, Theda. Bringing the State Back In. Cambridge: Cambridge University Press, 1985. TILLY, Charles. Coerción, capital y los estados europeos, 990-1990. Madrid: Alianza Editorial, 1992. MANN, Michael. Las fuentes del poder social, Il: el desarrollo de las clases y los estados nacionales, 1760-1914. Madrid: Alianza Editorial, 1993. POGGI, Gianfranco. El desarrollo del Estado moderno: una introducción sociológica. Buenos Aires, Universidad Nacional de Quilmes, 1997.

4

LÓPEZ-ALVES, Fernando. State formation and democracy in Latin America, 1810-1900. Durham: Duke University Press, 2000. CENTENO, Miguel Ángel. Blood and Debt. War and the Nation-State in Latin America. University Park : Pennsylvania State University Press, 2002.

BONNEY, Richard (ed.). Economic systems and state finance. The Origins of the Modern State in Europe, 13th-18th centuries. Oxford: Oxford University Press, 1995. CARDOSO, José Luis; LAINS, Pedro (eds.). Paying for the liberal state. The rise of the public finance in nineteenth-century Europe. Cambridge: Cambridge University Press, 2010. McNEILL, William. La búsqueda del poder. Tecnologia, fuerzas armadas y sociedad desde el 1000 d.C. Madrid: Siglo XXI, 1988. MEYER, John W.; BOLI, John; THOMAS, George M.; RAMÍREZ, Francisco 0. World society and the nation State. American Journal of Sociology, n. 103, p. 144-181, 1997.
Una revolución cultural

Los estudios sobre la construcción de los estados nacionales aparecen dominados por dos paradigmas que conviene someter a discusión. Por un lado, el paradigma de la continuidad, en virtud del cual el Estado nacional contemporáneo se presenta como la culminación de un proceso iniciado con la aparición de las monarquías absolutas en los siglos XV al XVII. Según esa visión, el Estado de la Edad Contemporánea sería un perfeccionamiento del Estado embrionario conocido ya en la Edad Moderna, al que solo añadiría la separación de poderes, el gobierno representativo, la garantía constitucional de las libertades individuales y una última mejora "tecnológica" en cuanto a la eficacia de los aparatos burocráticos. ${ }^{2}$ La perspectiva dominante, basada en esa continuidad del proceso de modernización ligado a la construcción estatal, resulta consoladora. Sostiene una visión de progreso continuo del cual seríamos beneficiarios los ciudadanos de nuestro tiempo. Pero omite los muchos elementos de ruptura que marcaron el proceso revolucionario, haciendo del Estado de los siglos XIX al XXI algo esencialmente diferente de las Monarquias anteriores.

El otro paradigma victorioso en el acercamiento al fenómeno histórico de la construcción de estados es el del Estado fiscal (fiscal state), creado y sostenido principalmente desde la sociología histórica. ${ }^{3}$ El caso de América Latina ha permitido a algunos autores discutir la universalidad del paradigma e introducir excepciones, pero sin proponer un enfoque alternativo. ${ }^{4}$ Este tipo de explicación lleva a considerar la construcción de los estados nacionales como un proceso de acumulación de recursos en manos de un poder centralizado. Entre esos recursos, fundamentalmente materiales, destaca la capacidad extractiva de los gobiernos. Estos conseguian, mediante un reforzamiento progresivo de los mecanismos fiscales, allegar presupuestos crecientes y financiar con ello tanto burocracias civiles como -sobre todo- ejércitos. Asi aumentaban su capacidad para ejercer la fuerza sobre la población y el territorio, haciendo frente a la amenaza de estados vecinos o de fuerzas disidentes. ${ }^{5}$

Uno y otro paradigma encajan bastante bien en las visiones clásicas de la construcción estatal. En ellas, la complejidad de la construcción de estados a lo largo de los cinco últimos siglos queda reducida a un mecanismo semiautomático de causas materiales: la acumulación de capital, la estructura de clases, la guerra, la fiscalidad y la burocracia se encadenan, equiparando procesos desarrollados en contextos culturales muy dispares. Pero de esta manera se ignora el sentido que los actores dieron al concepto de Estado y a su propia participación en la construcción del mismo.

Las carencias de estas aproximaciones a la construcción de los esta- 
ETZIONI, Amitai. A self-restrained approach to Nation Building by foreign powers. Foreign Affairs, n. 80-1, p. 1-17, 2004. FUKUYAMA, Francis. Statebuilding: Governance and World Order in the 21st Century. Ithaca, New York: Cornell University Press, 2004.

STEINMETZ, George (ed.). State/Culture. State Formation after the Cultural Turn. Ithaca, New York: Cornell University Press, 1999. El Third World Quarterly dedicó un número monográfico en 2006 a la necesidad de corregir el desequilibrio entre los estudios de construcción de estados y de construcción de naciones ("From Nation-building to State-building").

BOURDIEU, Pierre. Sur l'Etat: Cours au Collège de France (1989-1992). Paris: Seuil, 2012. dos históricos empezaron a resultar palpables a partir del giro culturalista de la historiografía en los últimos decenios del siglo XX. Un nuevo clima intelectual puso de manifiesto el divorcio inconcebible entre la tradición investigadora del Estado fiscal-militar y otras tradiciones igualmente ricas, pero desconectadas de aquella; por ejemplo, las que tienen que ver con la historia del pensamiento político (renovada por corrientes como la historia de los conceptos o la historia de las culturas políticas) y con la historia del derecho (renovada con la lectura densa de la doctrina jurídica).

Simultáneamente, el no final de la Historia que acompañó y siguió a la desaparición de la Unión Soviética dio un impulso extraordinario a los llamados State-building studies. Esta nueva área de trabajo busca implementar sobre el terreno atajos pragmáticos para edificar estados sólidos que estabilicen áreas del planeta como la península de los Balcanes, Oriente Medio o el África sud-sahariana. ${ }^{6}$ En esos estudios no resulta aprovechable la idea de que un Estado contemporáneo eficaz proviene del perfeccionamiento secular de viejas monarquías absolutas; ni tampoco la de que una construcción estatal exitosa resulta de concentrar recursos fiscales y militares en manos de un poder fuertemente centralizado, desentendiéndose del contexto cultural en el que eso ocurre. La reconstrucción de las estructuras estatales en países demolidos, como Siria, Irak, Afganistán o las repúblicas exsoviéticas o exyugoslavas, pasa por reconstruir previamente nuestra concepción del fenómeno estatal y del proceso histórico que llevó a su aparición y desarrollo.

Algunos trabajos pioneros han llamado la atención sobre la necesidad de reorientar y enriquecer los estudios sobre la construcción del Estado desde una perspectiva cultural.7 Pero, en general, las respuestas a la necesidad clamorosa de emprender una historia cultural de la construcción de los estados se han articulado alrededor del concepto de nación; parece como si todo lo que esta palabra encierra pudiera funcionar como dimensión cultural del fenómeno, reservando el término de estado para las dimensiones de carácter institucional, burocrático o material. Particularmente en paises en los que la identidad nacional sigue siendo hoy en día una cuestión política palpitante y conflictiva -como ocurre en el caso de España- la consideración de la construcción del Estado como proceso cultural ha derivado inevitablemente hacia la historia de la construcción de la nación, objeto esencialmente mental, lingüístico y cultural. Como en tantos otros aspectos, la nación oscurece más de lo que aclara, e impide ver otras dimensiones de un proceso histórico tan fuertemente cultural como fue -en España y en todas partes- la construcción del Estado.

La dimensión cultural de la construcción de los estados resulta, sin embargo, evidente: todo el constructo estatal se sostiene sobre la base de la legitimidad que los gobernados le conceden a esa forma de poder, a sus instituciones y a sus representaciones. Por eso, Pierre Bourdieu ha insistido en que la definición weberiana del Estado debería completarse, añadiendo que el Estado se define no sólo por poseer el monopolio de la violencia física legítima, sino también el monopolio de la violencia simbólica. ${ }^{8}$ Esto iba tal vez implícito en la idea de legitimidad de Max Weber, que exigía una transformación cultural, mental, en el interior de los gobernados; pero en nuestros días parece necesario resaltarlo y poner la dominación simbólica en el mismo plano que la dominación por la mera fuerza.

Para que el Estado nacional pueda existir es necesario todo un conjunto de transformaciones que pertenecen al ámbito cultural, en virtud de las cuales no sólo se acepta la legitimidad del poder, sino que los ciudadanos 
CORRIGAN, Philip; SAYER, Derek. The Great Arch: English State formation as cultural revolution. Oxford: Blackwell, 1985

10

Similar a la "historia conceptual de lo político" que propone ROSANVALLON, Pierre. Por una historia conceptual de lo político. Madrid: Fondo de Cultura Económica, 2006.

\section{1}

Esa visión compleja del Estado como campo de fuerzas en el que se libran batallas entre los grupos sociales ha sido puesta de manifiesto por el importante proyecto de investigación europeo dirigido por Juan Carlos Garavaglia sobre la construcción del Estado en América Latina (European Research Council Advanced Grant 230246: A Comparative History of the State Building process in Latin America, 1820-1870 (2009-2013). De ese proyecto se han publicado ya la mayor parte de sus resultados: GARAVAGLIA, Juan Carlos (ed.). Recaudar y reconstruir el Estado. Illes i imperis, n. 13, p. 7-213, 2010. GARAVAGLIA, Juan Carlos; GAUTRAEU, Pierre (eds.). Mensurar la tierra, controlar el territorio: América Latina, siglos XVIII-XIX. Rosario, Argentina: Prohistoria, 2011. GARAVAGLIA, Juan Carlos; PRO, Juan; ZIMMERMANN, Eduardo (eds.). Las fuerzas de guerra en la construcción del Estado: América Latina. Rosario: Prohistoria, 2012. GARAVAGLIA, Juan Carlos; PRO, Juan (eds.). Latin American Bureaucracy and the State Building Process (1780-1860). Newcastle: Cambridge Scholars, 2013. CONTENTE, Claudia (ed.). Justicia, violencia y construcción estatal. Illes $i$ imperis, n. 15, p. 7-193, 2013. LÓPEZ TAVERNE, Elvira. El proceso de construcción estatal en Chile: hacienda pública y burocracia (1817-1860). Santiago de Chile: Dibam - Centro de Investigaciones Diego Barros Arana, 2014. LÓPEZ BEJARANO, Pilar. Un Estado a crédito: Deudas y configuración estatal de la Nueva Granada en la primera mitad del siglo XIX. Bogotá: Pontificia Universidad Javeriana, 2015. GARAVAGLIA, Juan Carlos; LAMOUROUX, Christian; BRADDICK, Michael J. (eds.). Serve the Power(s), Serve the State. America and Eurasia. Newcastle: Cambridge Scholars (en prensa). ETCHECHURY BARRERA, Mario. Hijos de Mercurio, esclavos de Marte. Mercaderes y servidores del Estado en una frontera sud-atlántica: Montevideo, 1806-1860. Rosario, Argentina: Prohistoria (en prensa). GARAVAGLIA, Juan Carlos. La disputa por la construcción nacional argentina. Buenos Aires, la Confederación y las provincias, 1850-1865. Buenos Aires: Prometeo (en prensa). RODRÍGUEZ SOLANO, Pablo. Desconcierto, incertidumbre y hacienda pública: la construcción de Estado de Costa Rica (1821-1859). San José de Costa Rica: Universidad de Costa Rica (en prensa). RíOS, Evangelina de los. Una recaudación depurada de toda costumbre viciosa. Santa Fe, 1852-1873. Rosario, Argentina: Prohistoria (en prensa). CASELLI, Elisa (ed.). Justicias, agentes y jurisdicciones. De la Monarquía Hispánica a los Estados Nacionales (España y América, siglos XVI-XIX). Madrid: Fondo de Cultura Económica (en prensa).

12

REDDY, William M. The Navigation of Feeling: A Framework for the History of Emotions. CambridgeNew York: Cambridge University Press, 2001. adoptan una visión de la realidad mediada y condicionada por el Estado. Estos acaban interiorizando una visión estatal de la realidad a través de la educación, del lenguaje oficial, de las representaciones simbólicas visuales y de muchas otras maneras sutiles de moldear la mente de los gobernados. Se interioriza una visión estatal del Estado, que es la que nosotros tenemos asumida; esto nos impide ver con claridad en qué consiste la dominación estatal, ya que algunas de sus manifestaciones las tenemos naturalizadas y ni siquiera concebimos otra forma posible de ser o de pensar las cosas. Pensemos, por ejemplo, en la manera en que se presentan las estadisticas oficiales, o en las categorias mentales implícitas en los formularios burocráticos que como ciudadanos rellenamos todos los días: pensemos en los supuestos que aceptamos al tratar con esos documentos, que conllevan toda una visión del mundo.

Al término de este proceso de conformación estatal de las mentalidades colectivas, el Estado es ya una realidad mental tanto o más que una realidad institucional: es tanto interior o subjetivo como exterior u objetivo. Pero para llegar a ese resultado, ha sido necesario un proceso de cambio cultural, desde las formas no-estatales de convivencia y de institucionalización del poder hasta esta fórmula del Estado-nación, propia del mundo contemporáneo. Por esa razón, hay autores como Corrigan y Sayer que han llegado a concebir la construcción histórica del Estado (en su caso, el Estado inglés) como una verdadera revolución cultural. ${ }^{9}$

Esa dimensión cultural de la construcción del Estado puede abordarse desde la historia cultural de lo político. ${ }^{10}$ Pero trabajar en ese ámbito requiere partir de la idea de que el Estado no es un objeto material, como parecen suponer algunos relatos históricos convencionales que tienden a reificarlo. Más bien es un campo imaginario en el que se producen conflictos de fuerzas, negociaciones, actos de poder, violencias simbólicas... además de la extracción y concentración de recursos que hacen visible el proceso y permiten llamarlo construcción propiamente. ${ }^{11}$

Un fenómeno como este de la construcción de un Estado implica aspectos culturales de tanta importancia como la definición del lenguaje, la apropiación y resemantización de las categorias con las que se piensa la vida, la creación de relatos sobre el pasado o la ordenación y denominación del territorio en el que se habita. Salta a la vista que todo ello no se limita a la adopción -o el rechazo- de una identidad nacional. La nueva historia de las emociones nos diria incluso que el proceso de construcción de un Estado implica una redefinición normativa del régimen emocional de la sociedad. ${ }^{12}$

$Y$, puesto que hablamos de lo intangible, de esa dimensión cultural de la construcción del Estado, nos interesan también los imaginarios que daban sentido a las acciones constructivas. Es decir, los proyectos acerca de lo que el Estado debería ser y por qué: el aspecto ideal que debería tener una vez construido. De lo que se trata en este campo es de rastrear tanto lo común como lo diverso, y de hacer el balance entre ambos. Por un lado, rastrear lo que hay de lenguajes y símbolos compartidos, de relatos y categorias de pensamiento capaces de vertebrar a toda una sociedad o a sectores significativos de ella. Por otro lado, dar cuenta de la pluralidad de imaginarios y proyectos que pugnaban por orientar en direcciones distintas la construcción de un mismo Estado. Por continuar con la metáfora arquitectónica habitual en este tema (State building): si en el primer caso buscamos identificar los cimientos culturales de la construcción del edificio estatal, en el segundo comparamos los diversos "planos" o diseños de los arquitectos 
13

Un análisis de las posibilidades de la historia de las culturas políticas en: PÉREZ LEDESMA, Manuel; SIERRA, Maria, (eds.). Culturas políticas: teoría e historia. Zaragoza: Institución «Fernando el Católicon, 2010. Este libro sirvió de preámbulo para un intento colectivo de aplicación de ese enfoque a la historia de España en la obra: PÉREZ LEDESMA, Manuel; SAZ, Ismael (dirs.). Historia de las culturas políticas en España y América Latina. Madrid-Zaragoza: Marcial Pons - Prensas Universitarias de Zaragoza, 2014-2015, 6 vols. (publicados los vols. 1, 2, 3 y 4).

14

ARTOLA, Miguel. La monarquía de España. Madrid: Alianza Editorial, 1999.

\section{5}

La existencia de esta quiebra, presente en los análisis de ARTOLA, Miguel. Los orígenes de la España contemporánea. Madrid: Instituto de Estudios Politicos, 1959, ha sido argumentada expresamente por MARTíNEZ DORADO, Gloria. La formación del Estado y la acción colectiva en España: 18081845. Historia social, n. 15, p. 101-118, 1993.

16

Por ejemplo, en la obra de TORENO, Conde de (José María Queipo de Llano). Historia del levantamiento, guerra y revolución de España. París: Librería Europea de Baudry, 1838. que compitieron para construir el edificio. La historia de las culturas políticas aporta herramientas para avanzar en las dos direcciones, profundizando en el conocimiento de la cultura política de un pais (en singular), así como de las culturas políticas históricas que albergaron diversos grupos políticos y sociales (en plural)..$^{13}$

\section{El caso español: de la Monarquía al Estado-nación}

El caso histórico de España permite abordar esa tensión entre la diversidad de proyectos concurrentes y la capacidad de algunos de ellos para arraigar con más fuerza que otros, asentando en el imaginario colectivo determinados elementos comunes. Probablemente, de los proyectos de Estado en competencia -los modelos de Estado que defendían cada partido o cada grupo social-, ninguno consiguió imponerse por completo; pero todos, incluso los más contestatarios, dejaron alguna huella en el resultado final, el Estado que realmente se construyó. Considerar esta tensión existente detrás del proceso histórico de construcción del Estado nos muestra que el resultado no estaba determinado desde el principio, sino que se fue definiendo en un marco de conflictos y consensos muy fluido. No había un proyecto "realista" destinado a triunfar en la lucha sobre otros de carácter más "utópico", sino un conjunto de imaginarios de Estado concurrentes, a los que sólo a posteriori asignamos etiquetas en función de la suerte que corrieron.

En España, como en otros paises de Europa, hubo un proceso de fortalecimiento del poder real y de racionalización de su administración durante el siglo XVIII. Esa centralización chocó con algunos límites infranqueables, como los que le oponian la necesidad de preservar los privilegios estamentales y corporativos, el poder de la Iglesia o las jurisdicciones señoriales y municipales. Lo que ello significó fue que, a pesar de los cambios que el reformismo de la dinastía borbónica trajo a la vieja Monarquía de los $\mathrm{Ha}-$ bsburgo, no fueron suficientes para convertirla en un verdadero Estado. ${ }^{14} \mathrm{La}$ Monarquía mantuvo su constitución fundamental al servicio de los intereses dinásticos.

La construcción del Estado nacional del siglo XIX no fue una continuidad o un perfeccionamiento de un proceso iniciado anteriormente. Fue un proceso nuevo, que sobrevino después de la profunda crisis que experimentó la Monarquía española a partir del hundimiento de la flota (Trafalgar 1805), la invasión francesa de la Península, las abdicaciones de Carlos IV y Fernando VII (1808), la larga guerra que se inició entonces (conocida en la historiografía actual como la Guerra de la Independencia) y la rebelión de los dominios americanos desde 1810, que acabaría llevando a su emancipación irreversible como estados independientes (hacia 1824). ${ }^{15}$ Este fue un proceso revolucionario en toda la extensión de la palabra. No por casualidad, los contemporáneos Ilamaron a la guerra de 1808-1814 la Revolución española, ${ }_{1}^{16}$ subrayando los componentes que tuvo de guerra civil, cambio de régimen y cambio estructural, de época, tanto o más que la resistencia patriótica contra los franceses (que sería el elemento que a la larga, elegiría privilegiar la historiografía española desde una óptica nacionalista). En los extensos territorios americanos de la Monarquia fue aún más visible es componente revolucionario que cerraba un modelo y dejaba abiertas las puertas para definir otro.

A partir de 1808 se abrió en la parte europea de España un largo 
17

FONTANA, Josep. La revolución liberal: política y hacienda en 1833-1845. Madrid: Instituto de Estudios Fiscales, 1977.

18

Tratado de paz y amistad, celebrado entre España y la República Mejicana en 28 de diciembre de 1836. S.I.: S.n., 1838. periodo de confusión, alternancias y vacío de poder, que se prolongaría al menos hasta el final de la Primera Guerra Carlista en 1840. Durante todo ese tiempo, el poder de hecho fue asumido por oligarquías locales semiindependientes, apenas supervisadas por un poder central intermitente e inoperante, en proceso continuo de redefinición institucional y con graves dificultades para hacer reconocer su legitimidad.

Las consecuencias de ese largo periodo de descentralización del poder entre 1808 y 1840 fueron cruciales para la historia de España y condicionaron el proceso de construcción del Estado que se inició inmediatamente. En las colonias americanas, las oligarquias que se habian hecho con el poder in situ no volvieron nunca a la obediencia del poder central, consolidando la emancipación de nuevas naciones como Estados independientes. Como consecuencia, la nueva construcción política española no podría permanecer amarrada al modelo tradicional de imperio. Era obligado optar por un modelo de Estado-nación, capaz de obtener los recursos no mediante el control superficial de grandes territorios, sino mediante el control intensivo de un territorio más compacto y reducido, al modo de Francia o de Prusia. Esta necesidad material de extraer recursos de forma intensiva obligaba a transformar las mentalidades de la población, hasta hacer que asumiera las nuevas cargas, obligaciones y solidaridades que exige un Estado-nación.

Hasta que terminara de realizarse esa transformación cultural, la construcción del Estado en la Península Ibérica y en las islas que conservó España pasaba por la negociación y la integración de las oligarquias locales, únicas que podian asegurar el control del territorio y la movilización de sus recursos. Esa movilización de recursos no era un objetivo abstracto ligado a proyectos deseables a largo plazo, sino una necesidad urgente de cada dia. Había que recaudar impuestos para pagar al ejército y a los servidores públicos, asi como reclutar soldados con los que hacer frente a las guerras: guerras coloniales (que se prolongaron hasta la segunda mitad de los años veinte, cuando cayó el último bastión español en Sudamérica -Chiloé, 1826y fracasó el último intento de reconquistar México -Barradas, 1829-); y, sobre todo, la brutal guerra civil carlista, que dividió a la familia real, llevó la sublevación a grandes zonas del país y puso en contra del Estado constitucional naciente a gran parte de la Iglesia católica, con el apoyo de potencias extranjeras tan influyentes como el Imperio austriaco.

A mediados de los años treinta, el poder de la Monarquía no podía caer más bajo: apenas ejercía control efectivo sobre más territorio que la ciudad de Madrid. Sus fuerzas armadas no conseguian contener la rebelión de los carlistas, por un lado, y por otro de las masas populares de las ciudades, que secundaban opciones políticas radicales de sentido contrario. El sistema fiscal heredado de la Monarquía llevaba años anquilosado y al borde de la bancarrota, situación que hubo que reconocer en 1836 declarando la suspensión de pagos de la deuda pública, aunque ello significara cerrar para España el acceso al crédito exterior. ${ }^{17}$ En aquel mismo año empezaba España a reconocer oficialmente la independencia de sus antiguos dominios americanos, aceptando el carácter irreversible de la pérdida del imperio, comenzando por México. ${ }^{18}$ La situación de hundimiento de todo lo que había significado la Monarquía española en el pasado se escenificó dramáticamente en 1837, cuando el pretendiente carlista al Trono se presentó al frente de sus tropas delante de Madrid y amenazó con tomar la capital, insuficientemente defendida.

Lo que se construyera en el futuro como Estado nacional tendría que 
19

PRO, Juan. The Origins of State Bureaucracy in Nineteenth Century Spain. In: GARAVAGLIA, Juan Carlos; LAMOUROUX, Christian; BRADDICK, Michael J. (eds.). Serve the Power(s), Serve the State. America and Eurasia. Newcastle, Cambridge Scholars (en prensa).

20

HERZOG, Tamar. Vecinos y extranjeros: hacerse español en la Edad Moderna. Madrid: Alianza Editorial, 2006. ser algo nuevo, puesto que nada -o muy poco- quedaba del antiguo sistema de poder de la Monarquía. Y en la definición de ese nuevo Estado pugnaban desde el comienzo tendencias muy diversas. En el entorno cortesano se disputaban el control sobre la reina niña y sobre el Gobierno (lo que implicaría el control sobre la educación de la futura reina y de la futura nación) sectores muy diversos: desde el liberalismo monárquico y conservador que acabaría cuajando en el Partido Moderado, hasta el liberalismo progresista, más consecuente en la apuesta por el constitucionalismo, las libertades y el sistema representativo. Igualmente diverso era el magma de los movimientos revolucionarios populares, donde el alineamiento con los militares y políticos progresistas convivia con tendencias democráticas o abiertamente republicanas como las que acabarian confluyendo en la formación del Partido Demócrata (1849). Ni que decir tiene que el campo reaccionario estaba atravesado por disidencias de similar calado, aunque no aparecieran de forma tan notoria mientras la autoridad del pretendiente al trono, don Carlos, les dio un símbolo de unidad. Pero incluso entonces resultaban evidentes las valoraciones desiguales de la cuestión territorial en la lucha por restaurar el Antiguo Régimen: el final negociado de la guerra en el Norte a cambio de preservar algunos de los privilegios de las provincias vascas fue visto por otros sectores del carlismo como una traición a los principios fundamentales de su causa.

La construcción del Estado español, pues, partió de esa base que hemos descrito de un poder completamente desmenuzado. Era una situación prácticamente confederal. El Gobierno central no poseía aún medios administrativos para conocer el territorio, para obtener recursos de él o para hacer cumplir las normas, si no era a través de la mediación de poderosos locales con los que tenía que negociar. Este es el origen de la estructura clientelar del poder político y de los partidos en la España del XIX, que culminaria en el fenómeno del caciquismo, denunciado durante la crisis de la Restauración. Antes de que ese tipo de denuncia hiciera aparición (en torno al movimiento regeneracionista y la crisis de 1898), el caciquismo sirvió como instrumento para suplir la falta de medios administrativos propios por parte del Gobierno. La relación clientelar con los caciques locales y regionales permitió controlar el territorio, mantener el orden, reclutar soldados y recaudar impuestos. Solo cuando el Estado empezó a ser capaz de realizar todas estas funciones por sí mismo -hacia finales del siglo XIX-, la realidad social y política del caciquismo empezó a ser criticada duramente por quienes aspiraban a un modelo de Estado más moderno. ${ }^{19}$

La fuerza del componente local en aquel Estado incipiente que se estaba construyendo era enorme: no sólo se partía de una situación en la que el poder estaba en la práctica en manos de los caciques o notables locales con los que había que negociar todo; sino que, además, la identidad local era, según todos los indicios, a la que se adherian más intensamente los ciudadanos (más que la identidad nacional o regional). ${ }^{20}$

Hacia la construcción material del Estado: la Administración

Construir un Estado desde este punto de partida fue un proceso lento, costoso y conflictivo. Las autoridades del nuevo Estado en construcción 
tenian que dotarse de medios para llegar por sí mismas hasta el último rincón del territorio y para prescindir de la mediación de los ayuntamientos y los notables locales. Obviamente, ese objetivo tenía unos costes, requería unas inversiones y competía con otras prioridades presupuestarias. El contexto financiero de escasez extrema frenaba el avance hacia una Administración pública moderna y eficaz. También ralentizaba el proceso la existencia de dificultades materiales, como las que imponían las grandes distancias y el relieve peninsular, la diversidad lingüística y las desiguales estructuras de poblamiento, barreras todas ellas que exigian tiempo, dinero e imaginación para ser vencidas por un diseño global de Administración centralizada y uniforme. Por último, también dificultaba el proceso la existencia de intereses contrapuestos: intereses contrarios a la centralización del poder, como los que venían del clero católico o de los notables locales, depositarios directos de un poder amenazado por la construcción efectiva del Estado.

Por todo ello, el proceso fue lento. Y esta es una de las claves para comprenderlo. Hablamos de una revolución que se demoró durante decenios y que conoció alternancias políticas tanto en el Gobierno como en la definición del régimen (como puede verse en el cuadro 1). Esto dio oportunidad de que en el diseño del Estado y en la definición de cada una de sus piezas intervinieran muchas manos, partidos diversos que no podian aspirar a que sus realizaciones se mantuvieran una vez que hubieran caído del poder. Ese telón de fondo que fue la inestabilidad política otorga especial relevancia a aquellas medidas que se mantuvieron a largo plazo, por lo que tienen de excepcionales: eran medidas que, o bien alcanzaron un consenso entre las diversas fuerzas políticas en disputa, o bien respondian de forma eficaz a necesidades urgentes, de manera que una vez adoptadas nadie pudo derogarlas.

Cuadro 1.- Alternancias de poder en la España del siglo XIX.

\begin{tabular}{|l|l|}
\hline Afrancesados & $1808-13$ \\
\hline Liberales revolucionarios & $1808-14,1820-23$ \\
\hline Monárquicos absolutistas & $1814-20,1823-33$ \\
\hline Moderados & $1834-35,1838-39,1844-54$ \\
\hline Moderados + Unión Liberal & $1856-68$ \\
\hline Progresistas & $1835-38,1840-43,1854-56$ \\
\hline Progresistas + Demócratas & $1868-1873$ \\
\hline Republicanos & 1873 \\
\hline Conservadores & $1874-81,1882-85,1890-92$ \\
\hline Liberales & $1881-82,1885-90,1892-94$ \\
\hline
\end{tabular}

El mejor ejemplo de una de esas medidas, que podriamos señalar como el primer hito en la construcción del Estado nacional, fue la división provincial de 1833. Sobre esa malla provincial se crearon los subdelegados de Fomento, transformados luego en gobernadores civiles, jefes políticos y gobernadores provinciales (ya en 1849). La división del territorio de la nación en provincias se hizo antes de dar a la Monarquía carácter constitucional. No fue una emanación del constitucionalismo liberal, sino una medida racionalizadora adoptada por políticos como Javier de Burgos, que trabajaron a caballo entre los últimos periodos de la monarquía absoluta de Fernando VII y los primeros de la transición hacia el liberalismo bajo 
21

GAY ARMENTEROS, Juan C. Política y administración en Javier de Burgos. Granada: Centro de Estudios Municipales y de Cooperación Interprovincial, 1993

22

BURGUEÑO, Jesús. Geografía política de la España constitucional: La división provincial. Madrid: Centro de Estudios Constitucionales, 1996.

23

CAJAL VALERO, Arturo. El gobernador civil y el estado centralizado del siglo XIX. Madrid: INAP, 1999.

24

MORAL, Joaquín del; PRO, Juan; SUÁREZ, Fernando. Estado y territorio en España, 1820-1930: la formación del paisaje nacional. Madrid: La Catarata Universidad Rey Juan Carlos, 2008. la regencia de María Cristina. ${ }^{21}$ La división provincial, inspirada por el modelo de los departamentos de la Revolución francesa, estuvo precedida por varios intentos anteriores fallidos..$^{22}$ Supuso estructurar el territorio nacional en 49 circunscripciones de tamaño relativamente homogéneo, en torno a una red jerarquizada de ciudades a las que se otorgaba el control y tutela sobre las áreas rurales circundantes. Desde esas capitales, un gobierno provincial ejercería la doble función de llevar la acción administrativa hasta el territorio, y al mismo tiempo mediar políticamente entre el Gobierno y la población. Andando el tiempo, esas dos funciones resultarian esenciales para el despliegue del Estado. Por un lado, la función de coordinar la acción administrativa sobre el territorio, porque esa administración periférica sería cada vez mayor, con más funcionarios y más tareas que desempeñar, en línea con la idea de que la construcción del Estado era fundamentalmente la construcción de una Administración pública que lo hiciera presente ante los ciudadanos y lo legitimara por la realización de obras y la prestación de servicios. Pero, por otro lado, también sería esencial la función de mediación política que los gobernadores provinciales ejercerían en el futuro entre el Gobierno central y la población, organizando las elecciones y encargándose del mantenimiento del orden público. ${ }^{23}$

Fueron varios los grupos que incidieron sobre la construcción del Estado y dejaron en él piezas duraderas en los diferentes momentos en que controlaron el poder. Cada uno de esos grupos introdujo en el conjunto piezas que respondian a su diseño global de los que debería ser el Estado. En el cuadro 2 puede verse un resumen de las más importantes de esas medidas.

La decisiva división provincial de 1833, que aún se mantiene hoy en día en sus trazos esenciales, se completo poco después con la creación del Tribunal Supremo y la división de las provincias en partidos judiciales (1834). Estas medidas tenian como finalidad reorganizar los tribunales de justicia, adaptándolos al esquema centralizado y homogéneo que constituía la matriz del Estado nacional: un Tribunal Supremo en Madrid, una red de audiencias repartida por el territorio, y una subdivisión final en circunscripciones menores que las provincias -los partidos- que asegurara la cercanía y la densidad de la red de juzgados. Aunque la Justicia conservaría grandes elementos de continuidad con las prácticas del Antiguo Régimen, y sería uno de los componentes del Estado liberal necesitados de reforma hasta fecha más tardía (al menos hasta la Ley orgánica del Poder Judicial de 1870), la organización de 1834 fue importante: los partidos judiciales que se crearon entonces acabarian siendo la clave para un ordenamiento del territorio más fino que el que permitían las provincias, desplegando muchos otros servicios de la Administración a través de las pequeñas ciudades erigidas en cabezas de partido. ${ }^{24}$

Cuadro 2.- Medidas fundamentales para la construcción del Estado español en el reinado de Isabel II (1833-1868).

\begin{tabular}{|l|l|l|}
\hline $\begin{array}{l}\text { Reformismo } \\
\text { borbónico } \\
\text { (absolutismo } \\
\text { tardío) }\end{array}$ & División provincial & 1833 \\
\cline { 2 - 3 } & Tribunal Supremo & 1834 \\
\cline { 2 - 3 } & Partidos judiciales & 1834 \\
\hline
\end{tabular}




\begin{tabular}{|c|c|c|c|c|}
\hline \multirow{6}{*}{$\begin{array}{l}\text { Partido } \\
\text { progresista } \\
\text { (liberalismo } \\
\text { revolucionario) }\end{array}$} & \multicolumn{3}{|c|}{ Desamortización eclesiástica } & $1836-41$ \\
\hline & \multicolumn{3}{|c|}{$\begin{array}{l}\text { Reconocimiento de la independencia de América } \\
\text { (México) }\end{array}$} & 1836 \\
\hline & \multicolumn{3}{|c|}{ Ejército nacional permanente (servicio militar) } & $1836-38$ \\
\hline & \multicolumn{3}{|c|}{ Abolición del diezmo } & $1837-41$ \\
\hline & \multicolumn{3}{|c|}{ Abolición de los señoríos } & 1837 \\
\hline & \multicolumn{3}{|l|}{ Constitución } & 1837 \\
\hline \multirow{13}{*}{$\begin{array}{l}\text { Partido } \\
\text { moderado } \\
\text { (liberalismo } \\
\text { conservador) }\end{array}$} & \multicolumn{3}{|l|}{ Guardia Civil } & 1844 \\
\hline & \multicolumn{3}{|l|}{ Reforma fiscal } & 1845 \\
\hline & \multicolumn{3}{|c|}{ Ley de Ayuntamientos } & 1845 \\
\hline & \multicolumn{3}{|c|}{ Unificación monetaria } & 1848 \\
\hline & \multicolumn{3}{|c|}{ Unificación de pesas y medidas } & 1848 \\
\hline & \multicolumn{3}{|c|}{ Red ferroviaria centralizada } & 1851 \\
\hline & \multicolumn{3}{|c|}{ Organización del funcionariado } & 1852 \\
\hline & \multicolumn{3}{|c|}{ Estadistica y cartografía } & 1856 \\
\hline & \multicolumn{3}{|c|}{ Sistema de instrucción pública } & 1857 \\
\hline & \multirow{4}{*}{$\begin{array}{l}\text { Adopción } \\
\text { de medidas } \\
\text { defendidas del } \\
\text { absolutismo } \\
\text { monárquico } \\
\text { (carlistas) para } \\
\text { integrarlo en el } \\
\text { sistema }\end{array}$} & $\begin{array}{l}\text { Reconocimiento } \\
\text { de privilegios } \\
\text { territoriales }\end{array}$ & $\begin{array}{l}\text { Restablecimiento } \\
\text { de los fueros } \\
\text { en País Vasco y } \\
\text { Navarra }\end{array}$ & $1839-41$ \\
\hline & & \multirow{2}{*}{$\begin{array}{l}\text { Confesionalidad } \\
\text { del Estado }\end{array}$} & $\begin{array}{l}\text { Contribución de } \\
\text { Culto y Clero }\end{array}$ & 1840 \\
\hline & & & $\begin{array}{l}\text { Concordato con la } \\
\text { Santa Sede }\end{array}$ & 1851 \\
\hline & & $\begin{array}{l}\text { Refuerzo del } \\
\text { poder de la } \\
\text { Corona }\end{array}$ & $\begin{array}{l}\text { Nueva } \\
\text { Constitución }\end{array}$ & 1845 \\
\hline
\end{tabular}

El movimiento revolucionario del verano de 1835, que llevó al poder a los progresistas de Juan Álvarez Mendizábal, puso en marcha una oleada de disposiciones más audaces y de carácter más decididamente liberal, que fue clave para que pudiera construirse un Estado nacional. Medidas adoptadas a despecho de la Corona y de su entorno cortesano, de la resistencia de la jerarquía eclesiástica y de la situación de guerra y de penuria financiera que vivía el país; pero medidas tan necesarias y de tal envergadura, adoptadas en los años 1835 a 1837, que ni sus adversarios pudieron desmantelar en los años posteriores. Estas medidas constituyen la fase final de la Revolución española, comenzada en 1808 , pero con tantos avances y retrocesos que sólo en este periodo que va de 1835 a 1840 puede darse por cerrada y triunfante con un cierto carácter irreversible.

La más importante y revolucionaria de esas medidas fue la llamada desamortización, es decir, la nacionalización masiva de los bienes de la Iglesia. El enorme patrimonio así obtenido, que la Iglesia católica había ido acumulando durante siglos, fue sacado en su mayor parte a la venta en pública subasta, saneando las arcas del Estado y allegando recursos financieros extraordinarios con los que financiar la creación de un Ejército permanente y de una Administración civil incipiente, dos atributos esenciales de cualquier Estado.

La operación encajaba perfectamente en los objetivos de la revolución liberal: por un lado, las tierras y las casas vendidas a particulares ampliaban la base social del liberalismo en España, creando una clase de compradores de bienes desamortizados cuyos intereses económicos quedaban ligados a la vigencia del régimen; por otro lado, los edificios nacionalizados y no ven- 
didos (iglesias, conventos, monasterios, colegios...) constituyeron la primera red de edificios públicos en la que se albergaron cuarteles, oficinas de la Administración, ministerios y hasta las dos cámaras parlamentarias. El dinero obtenido por las subastas permitió reclutar, uniformar y armar a un ejército con el que se acabaría ganando la guerra civil contra los carlistas. El saneamiento de la Hacienda pública y el patrimonio inmobiliario adquirido por el Estado abriría la posibilidad de avalar empréstitos extranjeros con los que impulsar la acción estatal. Por último, la desamortización conllevó una verdadera reforma de la Iglesia desde el Gobierno, operación de sometimiento al poder civil insólita en la historia de España: por un lado, el tamaño y estructura del clero fueron alterados drásticamente, al decretar la exclaustración del clero regular (el perteneciente a órdenes religiosas, que era la mayor parte) y reconocer como legítimo sólo al clero secular que ejercía funciones pastorales; por otro lado, ese clero secular superviviente a la reforma ya no se mantendría con sus propios recursos ni gozaría de la consiguiente independencia, sino que viviria de una llamada Contribución de Culto y Clero (creada en 1840) que convertía a los clérigos en asalariados del Estado, asimilándolos al funcionariado, y hacía depender del presupuesto del Estado la financiación del culto católico.

Esta trascendental reforma, verdadero núcleo de la revolución española, se completó con la abolición del diezmo eclesiástico (entre 1837 y 1841), impuesto que venía nutriendo las arcas de la Iglesia desde la Edad Media. El diezmo venía siendo en los últimos tiempos el impuesto más pesado y más ineludible que pagaban la mayoría de los contribuyentes, impuesto recaudado con más eficacia que los de la Hacienda real, gracias a la red de vigilancia y extracción que proporcionaban los curas párrocos. Su abolición y la consiguiente desaparición de una Hacienda eclesiástica independiente resultaban inexcusables para liberar de esa carga a los productores -en una economía predominantemente agrícola y ganadera- y permitir la imposición, en su lugar, de tributos estatales con los que configurar una verdadera Hacienda pública.

La nacionalización del patrimonio eclesiástico, la exclaustración del clero regular y la abolición del diezmo terminaron por sublevar a la Iglesia en contra de una revolución liberal a la que se había opuesto doctrinalmente desde el comienzo, aunque hubiera muchos clérigos que participaron a título personal en diversos niveles y facetas de este movimiento. El boicot de la Iglesia al nuevo Estado español es menos conocido que el que lanzó, por ejemplo, contra la Francia revolucionaria o contra la unificación italiana; pero fue igualmente virulento, pues el apoyo del Papado y de la jerarquía eclesiástica a la revuelta carlista fue solamente una más de las maneras en las que la Iglesia trató de acabar con las posibilidades de implantación del liberalismo en un pais de mayoría católica.

La abolición definitiva de los señoríos en 1837 completó lo realizado al abolir el diezmo eclesiástico, pues se eliminaban así, además de la Hacienda eclesiástica, las Haciendas señoriales que competían con la recaudación de la Hacienda real. La medida constituía una afirmación notoria del poder central y de la unidad nacional, tanto que había sido convertida por los liberales en un símbolo de su revolución, identificándola como la abolición del feudalismo en línea con el discurso de la Revolución francesa: por ello había

PRO RUIZ, Juan. La construcción del Estado en España, p.7; 36 . sido decretada antes varias veces por los liberales, en 1811 y 1823, antes de la definitiva de $1837 . .^{25}$ Ciertamente, la abolición de los señoríos implicaba mucho más que una uniformización fiscal: implicaba también -y sobre 
26

LORENTE, Marta; PORTILLO, José María (eds.). El momento gaditano: la constitución en el orbe hispánico (1808-1826). Madrid: Congreso de los Diputados, 2011.

27

FRADERA, Josep Maria. Colonias para después de un imperio. Barcelona: Bellaterra, 2004. todo- la unificación de las jurisdicciones, eliminando la justicia señorial en los territorios de señorío y estableciendo como atributo de la soberanía la existencia de una única jurisdicción definida sobre la base de los antiguos territorios de realengo.

Otra de las innovaciones fundamentales de 1837, que perduraria en el modelo de Estado español para todo el siglo, fue el cambio en la concepción de las posesiones coloniales que aún le quedaban a España: Filipinas, Puerto Rico y, sobre todo, Cuba, la joya de la Corona. La vieja idea de una Monarquía formada por reinos diversos en la Península y en las Indias había dejado paso con la Constitución de Cádiz (1812) a la idea de la "Nación de ambos hemisferios": una nación española formada por los ciudadanos de todos los territorios españoles en la Península y en América, todos ellos representados por sus diputados en las Cortes, con los mismos derechos constitucionales y sometidos a la misma legislación. ${ }^{26}$ Pero aquel modelo no había funcionado, en la medida en que no fue suficiente para atraer a los criollos al seno de la nación imaginada; y después de la independencia de los dominios americanos, que las propias Cortes de 1836 decidieron reconocer oficialmente, ya no tenía sentido mantenerlo. En un golpe de mano de dudosa legalidad, las Cortes elegidas en 1836 con arreglo a la Constitución de Cádiz expulsaron de la cámara a los diputados de Ultramar y definieron -sin ellos- un nuevo marco que distinguía entre la nación española (la Península e islas adyacentes) y sus dominios coloniales. Cuba, Puerto Rico y Filipinas pasaron entonces a ser vistas como partes de un imperio colonial que se regiría por unas "leyes especiales" que nunca llegaron, ya que en la práctica serían gobernadas militarmente al servicio de una explotación económica intensiva por parte de la metrópoli. ${ }^{27}$

El giro de 1836-37 fue decisivo, pues ocurría en un país que se veía ante todo como cabeza de un imperio desde hacia tres siglos: para los súbditos de la Monarquía española del Antiguo Régimen su lugar en el mundo venía dado por la lógica de los reinos a los que pertenecian, de los ordenamientos dispares que estos tenían y de las relaciones establecidas por cada uno tanto con la Corona como con el conjunto de los otros reinos que integraban la Monarquía. Tras darse por fracasado el intento de 1810-1836 de convertir sin más aquella Monarquía compuesta en una única nación, abarcando las dos orillas del Atlántico, el nuevo proyecto que inspiraria las lógicas políticas durante el resto del siglo sería el de construir un Estado basado en la nación española -limitada ya a los territorios españoles de la península e islas adyacentes- y el dominio autoritario de esta sobre un imperio colonial, aunque en el mismo quedaran ya solo las posesiones insulares de Cuba, Puerto Rico y Filipinas (a las que fugazmente se añadió Santo Domingo en 1861-65). La concepción de España cambiaba radicalmente con este salto de ser pensada como una Monarquía compuesta a ser pensada como una nación metropolitana que poseía un imperio colonial; y esta imagen pervivió hasta la pérdida de las colonias en 1898. La separación de los dominios ultramarinos, dejándolos aparte del desarrollo constitucional de la metrópoli, permitió avanzar más rápido en la definición integradora de España como nación y en la negociación de los derechos y obligaciones que definirian la noción de ciudadano. Pero sería un error pensar que el imperio colonial pasó a ser un apéndice irrelevante para la evolución metropolitana hacia un verdadero Estado-nación. Al contrario, el espacio colonial tuvo una incidencia estructural sobre la construcción del Estado español en el siglo XIX: no solo por la extracción directa de recursos que suponía la dominación 
28

PUELL DE LA VILLA, Fernando. Historia del ejército en España. Madrid: Alianza Editorial, 2000.

29

PRO, Juan. El Estatuto Real y la Constitución de 1837. Madrid: Iustel, 2010. imperial sobre los territorios coloniales y el consiguiente efecto de aceleración sobre la acumulación capitalista. Sino también por la creación de un marco cultural dominado por el concepto de imperio en el que las colonias funcionaron como verdaderos laboratorios de soluciones institucionales y materiales para abordar los problemas de la modernidad, frecuentemente en una línea autoritaria como la que promovían en las colonias el estilo de gobierno militar, la negativa a la participación de los gobernados y el designio indisimulado de ejercer una explotación económica intensiva de los recursos del territorio.

Con los recursos que se obtuvieron -o que se esperaban obtener en años venideros- de la desamortización eclesiástica, Mendizábal lanzó en 1836 la "quinta de los 100.000 hombres". El nombre recuerda, sin duda a la levée en masse de la Revolución francesa (1793) y, de hecho, tuvo un efecto parecido, pues movilizó un gran ejército capaz de salvar al régimen liberal de sus enemigos armados. En realidad, nunca se llegaron a reclutar 100.000 soldados, por lo que el nombre tuvo algo también de golpe de efecto propagandístico; pero sí fue una movilización significativa, que puso en manos del Ejército una fuerza de unos 265.000 hombres al año siguiente, fuerza incomparablemente mayor de la que había tenido hasta entonces o de la que podía movilizar el adversario. ${ }^{28}$ La creación del Ejército nacional partió de esa base y se completó con la creación del cuerpo de Estado Mayor en 1838, la unificación de la fuerza armada en 1847 y su sometimiento íntegro al Ministerio de la Guerra en 1850.

Fue con ese Ejército con el que el general Espartero derrotó a los carlistas, pactando en 1839 la rendición del mayor de sus contingentes en Vizcaya (Pacto de Vergara). Tras la reducción de los últimos focos de resistencia en 1840, la estabilidad y la fuerza así logradas permitieron avanzar más deprisa en la construcción del Estado. Si el periodo de gobierno de los progresistas permitió romper con el Antiguo Régimen y consolidar un régimen liberal, que se plasmó en la Constitución de 1837, ${ }^{29}$ la llegada de los moderados al poder a partir de 1843 hizo entrar al proceso de construcción del Estado en una nueva fase. La aportación de los moderados consistió, por un lado, en estabilizar la situación imponiendo un orden conservador que diera paso a un periodo claramente postrevolucionario. Y por otro lado, en materializar la construcción del Estado mediante el desarrollo de una Administración pública centralizada que unificara el territorio y lo pusiera bajo el control efectivo del Gobierno. Esta vía de la Administración fue la elegida por los moderados, siguiendo fundamentalmente modelos franceses, para poner fin a las convulsiones revolucionarias y a la autonomía local.

Al mismo tiempo, en línea con su programa conservador, los moderados trataron de reconducir hacia el orden en el que creían algunas de las medidas más avanzadas de los progresistas: corrección conservadora del modelo, pero sin desmantelar en lo esencial la definición del Estado-nación ni del régimen de monarquía constitucional. Este giro conservador se llevó hasta los límites de lo posible con el fin de atraer al sistema a los partidarios del carlismo, una vez derrotado en los campos de batalla a partir de 183940. Con ello, los moderados esperaban no solamente reforzar la estabilidad del régimen de Isabel II, integrando en él a los monárquicos absolutistas dispuestos a olvidar el pleito dinástico; sino también reforzar sus propias posiciones políticas, engrosando las filas del partido con la afluencia de cuadros, notables y apoyos sociales que hasta entonces habian sido carlistas.

Así, se aprovechó la ambigua promesa realizada a los carlistas vizcaí- 
30

JOURNEAU, Brigitte. Eglise et état en Espagne au XIXe siècle: les enjeux du concordat de 1851. Villeneuve d'Ascq: Presses Universitaires du Septentrion, 2002.

ARTOLA, Miguel. El modelo constitucional español de/siglo XIX. Madrid: Fundación Juan March, 1979. nos en el momento de su rendición por el Convenio de Vergara (1839) para restaurar el régimen foral de las provincias vascas y de Navarra, un régimen de privilegios territoriales heredado del Antiguo Régimen y abiertamente contradictorio con los principios de igualdad jurídica y fiscal recogidos en la Constitución. Tras esta importante concesión a los carlistas del Norte, vinieron otras medidas igualmente atractivas para ellos. Concluida la guerra, se abrió una vía de negociación con Roma: como fervientes católicos, estaban muy interesados en obtener la reconciliación y las bendiciones de la Iglesia tanto la familia real como la plana mayor del Partido Moderado -que en definitiva era el partido organizado desde la corte y dirigido por la familia real misma. La falta de legitimidad que representaba el anatema lanzado desde la Iglesia contra el régimen de Isabel II podría haber acabado pasándole factura en un país de abrumadora mayoría católica; pero, en todo caso, significaba un problema de conciencia para sus dirigentes, cuestión que no puede dejarse al margen al considerar los motivos por los que se abrió una negociación y se realizaron importantes concesiones a la Iglesia. Por un lado, se garantizó el sostenimiento económico del clero, de los templos y de las actividades de la Iglesia mediante la llamada Contribución de Culto y Clero. La negociación fue más larga, dura y difícil de lo esperado; pero se acabó concretando con la firma del Concordato de 1851, por el que Roma reconocía al nuevo Estado español. ${ }^{30}$

Con estas medidas, quedaba definida la confesionalidad del Estado, otro rasgo -junto con los privilegios territoriales del País Vasco- que definiría estructuralmente al Estado español hasta la actualidad y que estaría preñado de consecuencias políticas, económicas y sociales. Faltaba solo un paso más para hacer aceptable el Estado español a los ojos de los antiguos carlistas, y ese paso se dio en 1845: una reforma de la Constitución que la descargó de elementos liberales y representativos, reforzando el poder de la Corona sobre todo el sistema político. Posteriormente, los progresistas intentaron cambiar de nuevo el marco constitucional con un texto que no tuvieron tiempo de promulgar (la Constitución nonata de 1856) y otro que sí (la Constitución de 1868); y los conservadores volvieron a implantar una constitución acorde a sus principios en 1876. Pero toda esta inestabilidad constitucional de la España del XIX es más aparente que real, pues por debajo del cambio continuo de textos constitucionales se descubre la permanencia de los trazos básicos de una monarquía constitucional, un estado unitario y un parlamento bicameral. ${ }^{31}$

La llegada al poder del Partido Moderado en 1843-44, pues, no detuvo la construcción del Estado nacional, sino que la orientó en una dirección parcialmente distinta de la que le habian dado los progresistas en $1835-37$ y $1840-43$. No hubo más medidas revolucionarias, en el sentido de reducir los privilegios ni de desafiar los intereses de la Iglesia; pero se intensificó el reforzamiento del poder central y el despliegue por el territorio de una Administración a su servicio. De hecho, un grupo de administrativistas vinculados al Partido Moderado (Alejandro Oliván, Ramón de Santillán, Antonio Gil de Zárate, Javier de Burgos, Manuel Ortiz de Zúñiga) diseñó en esos años un modelo de Estado propio, inspirado tanto por el administrativismo francés (Bonin, Cormelin, Bouron-Leblanc, Gaudillot, Macarel) como por las prácticas locales del gobierno político y económico de los pueblos asentadas en la España del Antiguo Régimen. Ese ideal administrativista de Estado grande orientó la construcción del Estado de manera directa durante los diez años de la llamada década moderada (1844-1854) e indirectamente 
32

PRO, Juan. Los administrativistas españoles del XIX y su Estado ideal. Historia y Política, n. 36, 2016 (en prensa). PRO, Juan. El modelo francés en la construcción del Estado español: el momento moderado. Revista de Estudios Políticos (en prensa).

33

LÓPEZ GARRIDO, Diego. La Guardia Civil y los origenes del estado centralista. Barcelona: Crítica, 1982.

34

ESTAPÉ, Fabián. La reforma tributaria de 1845: Estudio preliminar y consideración de sus precedentes inmediatos. Madrid: Instituto de Estudios Fiscales, 1971. FONTANA, Josep. op. cit.. ARTOLA, Miguel. La hacienda del siglo XIX:progresistasymoderados. Madrid: Alianza Editorial, 1986. FUENTES QUINTANA, Enrique. Las reformas tributarias en España: teoría, historia y propuestas. Barcelona: Crítica, 1990. COMÍN, Francisco; VALLEJO, Rafael. Alejandro Mon y Menéndez (1801-1882): pensamiento y reforma de la Hacienda. Madrid: Instituto de Estudios Fiscales, 2002. después, durante la última parte del reinado de Isabel II (1856-1868), bajo el régimen de la Restauración borbónica (1874-1923) e incluso bajo las dictaduras de Primo de Rivera (1923-1931) y Franco (1939-1975). Dicha concepción del Estado, estrictamente centralizado, uniformizador, autoritario y jerárquico, postergaba los elementos de participación, libertades y representación política, identificando al Estado con la Administración y poniendo en el despliegue de esta última su fuente principal de legitimidad. ${ }^{32}$

Aquel modelo de Estado administrativo estaba llamado a compensar por la vía de las obras, los servicios y las realizaciones materiales la restricción de las libertades y del derecho de participación política. Por ello, un paso importante en su construcción fue la creación, entre 1847 y 1850 , del Ministerio de Fomento, que venía a añadirse a los ministerios clásicos de Estado, Guerra, Marina, Hacienda, Justicia y Gobernación, dando relevancia a las competencias estatales en la construcción de obras públicas, el impulso al comercio, la industria y la agricultura, la instrucción pública y la protección a las artes y la cultura. Este fue el imaginario de Estado dominante entre los amplios sectores del nacionalismo conservador de los que salieron las elites que dirigieron la construcción del Estado en periodos largos y decisivos como los que se han señalado. Por ello, es un modelo que tuvo más influencia que otros sobre el resultado final, aunque como modelo imaginario tuviera algo de irrealizable, y sus propios partidarios lo traicionaran en algunos aspectos. Sobre todo porque la construcción efectiva de un Estado grande como el que preconizaban aquellos administrativistas hubiera requerido traspasar dos límites que no estaban dispuestos a traspasar los dirigentes de aquella formidable coalición de intereses que constituyó el Partido Moderado: por un lado, hubiera requerido invertir grandes recursos financieros para aumentar el número de funcionarios y los medios materiales para que estos pudieran actuar con eficacia, y ello hubiera requerido un aumento de la presión fiscal que tendria que recaer sobre los grandes propietarios que sostenian al moderantismo; por otro lado, hubiera dado a la Administración central un enorme poder para actuar por sí misma en todo el territorio, haciendo perder autonomía y capacidad de negociación a las oligarquias locales que formaban también, en gran medida, la base que sostenía a los moderados. Ni una ni otra cosa podían hacerse sin debilitar las posibilidades del Partido Moderado de mantenerse en el poder, por lo que en la práctica los constructores del Estado tuvieron que moverse en el margen que quedaba entre el modelo teórico del Estado grande al que aspiraban y las imposiciones de una realidad que les impedian alcanzarlo plenamente.

Con esas limitaciones, sin embargo, la sucesión de realizaciones para construir Estado fue considerable en aquellos años. En 1844 se creaba la Guardia Civil, instituto armado para el control del orden público en las zonas rurales, que ha desempeñado históricamente funciones mucho más amplias hasta el punto de constituir el más eficaz instrumento de control gubernamental hasta nuestros dias. ${ }^{33}$ En 1845 se aprobaba la reforma tributaria de Alejandro Mon, que ponía fin a la pervivencia de los impuestos del Antiguo Régimen, unificaba los sistemas fiscales de las antiguas Coronas de Castilla y Aragón, y perfilaba un esquema fiscal estable, capaz de perdurar durante más de cien años. ${ }^{34}$

En el mismo año 1845 los moderados impusieron su Ley de Ayuntamientos, después de una disputa de varios años con la alternativa que defendian en este terreno los progresistas. La medida era decisiva, pues los progresistas apostaban por dar a los ayuntamientos un grado de represen- 
CASTRO, Concepción de. La revolución liberal y los municipios españoles (1812-1868). Madrid: Alianza Editorial, 1979. tatividad electiva y de autonomía policía que los convirtiera en auténticos poderes locales (visión cuasi democrática del poder local que iba acompañada de la dotación de una fuerza armada propia, la Milicia Nacional, fuerza politizada de ciudadanos en armas para defender el orden constitucional, que los ayuntamientos encuadraban y dirigian). Por el contrario, los moderados impusieron un sistema que vaciaba a los ayuntamientos de representatividad y de verdadero poder político: elegidos los concejales por un sufragio fuertemente censitario, la designación del alcalde era potestad del Gobierno, y el Ayuntamiento en pleno se concebía como el último escalón de la Administración, representante del Estado ante los vecinos y no de los vecinos ante el Estado. ${ }^{35}$ El cambio se completaba con la abolición de la Milicia Nacional, decretada en 1843, haciendo que los cuerpos de control del orden público (Ejército y Guardia Civil) fueran instrumentos del Gobierno y no fuerzas autónomas al servicio del poder local.

El sometimiento formal de los ayuntamientos al poder central era crucial para que pudiera funcionar sin distorsiones el Estado autoritario y centralista que los moderados buscaban. Puesto que no era posible -al menos por el momento- que funcionara el Estado grande a pleno rendimiento, ya que no había dinero ni funcionarios suficientes como para hacer que la Administración llegara por sí misma hasta el último rincón del territorio, había que someter a los ayuntamientos para que actuaran como prolongación del poder del Gobierno en cada ciudad o pueblo del pais. Ese fue el sucedáneo del Estado grande de los administrativistas que funcionó en la práctica durante la mayor parte del siglo XIX: el de un Estado que se hacía presente en la sociedad y en el territorio a través de los ayuntamientos y no de sus propios funcionarios y servicios. Esto convertía en mecanismo fundamental del Estado la cadena de mando que iba desde el Gobierno central situado en Madrid hasta los 49 gobernadores provinciales, y a través de estos hasta los 9.000 ayuntamientos que, de hecho, gestionaban la vida diaria de la población.

Lo cierto es que ni siquiera este sucedáneo pudo funcionar plenamente con el grado de homogeneidad que tenía en el imaginario de los administrativistas, ya que se interponian en ese objetivo otros planteamientos y otros intereses que era necesario respetar. En el Pacto de Vergara, que puso fin a la Primera Guerra Carlista en 1839, se había prometido a los carlistas del Norte, a cambio de la rendición, que se mantendrian ciertos privilegios económicos y un cierto margen de autogobierno a las provincias forales del Pais Vasco y Navarra. Estas cuatro provincias se fueron integrando gradualmente en el Estado nacional, pero en condición asimétrica, con sucesivos avances en 1841,1844 y 1848 . El resultado final no era el de una completa homogeneidad del territorio: las provincias forales, por ejemplo, mantuvieron su propio sistema fiscal, diferenciado del de las otras 45 provincias llamadas "de régimen común". También mantenían regímenes separados en cuanto al sistema estadístico o al reclutamiento militar. Pero, sobre todo, mantenían una autonomía política de la que no disponian las demás provincias, de manera que en las Provincias Vascas y Navarra el Gobierno central tenía que negociar directamente con las diputaciones forales, que representaban al conjunto de la provincia, y no con cada ayuntamiento.

El modelo de negociación que en el resto del país se hacía a través de una cadena de mando con tres niveles -Gobierno central, gobernador provincial y municipio-, se hacía con solo dos niveles en el País Vasco y Navarra, donde el Gobierno central negociaba con las respectivas diputaciones. El 
resultado era una capacidad de negociación mucho mayor en manos de las cuatro provincias forales, que podian preservar sus intereses y sus privilegios con mayor eficacia a largo plazo. Las cuatro provincias se integraban en el Estado-nación que se estaba creando, pero en condiciones especiales, que daban al Estado resultante una cierta asimetría.

\section{Estado, mercado y nación}

La definición del orden político y administrativo del Estado iba acompañada de otras tareas que revestían tanta importancia o más en cuanto a inscribir el Estado en las mentes de los ciudadanos: por un lado, medidas destinadas a uniformizar cultural y lingüisticamente el pais, haciendo de él una nación en la que imperaran imaginarios similares; por otro lado, medidas destinadas a crear un mercado nacional único que diera también sentido económico a la unificación legislativa y cultural que se estaba produciendo. En ambos terrenos -que se reforzaban mutuamente-, habia que hacer frente a un alto grado de diversidad y de compartimentación que venía del proceso histórico de agregación por el que las dinastías reinantes habían ido reuniendo en una sola mano territorios diversos desde la Edad Media.

Así, por ejemplo, en el terreno económico, habria que resaltar la importancia que tuvo para la unificación de los mercados la ya mencionada reforma tributaria de 1845 , pero también la unificación monetaria (lograda trabajosamente en torno al real primero, después al escudo y finalmente a

MARTORELL, Miguel. Historia de la peseta: la España contemporánea a través de su moneda. Barcelona: Planeta, 2002.

37

TEDDE DE LORCA, Pedro. Los primeros ciento cincuenta años del Banco de España (1782-1931). In: MARTÍN ACEÑA, Pablo; TITOS MARTíNEZ, Manuel (eds.). El sistema financiero en España: una síntesis histórica. Granada: Universidad de Granada, 1999. P. 53-82.

38

ARTOLA, Miguel (ed.). Los ferrocarriles en España, 1844-1943, I: El Estado y los ferrocarriles. Madrid: Banco de España, 1978. COMíN, Francisco (ed.). 150 años de historia de los ferrocarriles españoles. Madrid: Fundación de los Ferrocarriles Españoles, 1998. la peseta entre 1848 y 1868), ${ }_{1}^{36}$ la unificación de pesas y medidas en torno al sistema métrico decimal (a partir de 1848), la creación de los sellos de correos (1850), la unificación del sistema bancario con la creación del Banco de España en 1856 (que refundía el Banco de Isabel II, de 1843, y el de San Fernando, de 1847) o la concesión a dicho Banco de España del monopolio de emisión de papel moneda (1874). ${ }^{37}$ Más allá de los efectos puramente económicos de estas medidas, hay que pensar también en los efectos simbólicos de la circulación de mercancias y dinero en un mercado unificado, particularmente cuando esa circulación hacía pasar de mano en mano objetos como los sellos, las monedas metálicas o los billetes, que representaban gráficamente los símbolos del poder del Estado, de la unidad nacional y de una visión estatista del pasado español.

Capitulo aparte merecería la creación de la red de ferrocarriles. En 1848 se inauguró la primera línea ferroviaria y enseguida, en 1851, se diseño desde el Gobierno una red centralizada de estructura radial que orientaria la construcción de los ferrocarriles españoles hasta finales del siglo XX. Durante un siglo y medio, por tanto, la prioridad de la red ferroviaria fue la de conectar la capital del Estado con todas las capitales provinciales, con los grandes puertos del Mediterráneo, el Cantábrico y el Atlántico, y con las fronteras terrestres que conectaban España con Francia y Portugal..$^{38} \mathrm{La}$ construcción de esa red, que ocupó toda la segunda mitad del siglo XIX, tenía un doble efecto sobre la construcción del Estado nacional: por un lado, cumplía el objetivo primordial de conectar al Gobierno con el territorio, permitiéndole una transmisión eficaz de información (ya que la red telegráfica siguió el trazado de las líneas ferroviarias) y un acceso material inmediato, que permitía enviar funcionarios o tropas, con el consiguiente efecto sobre la centralización efectiva del poder. Por otro lado, la red ferroviaria produjo una unificación eficaz del mercado nacional, que no había sido posible con 
MADRAZO, Santos. El sistema de comunicaciones en España, 1750-1850. Madrid: Colegio de Ingenieros de Caminos, 1984. GÓMEZ MENDOZA, Antonio. Ferrocarriles y cambio económico en España, 1855-1913: un enfoque de nueva historia económica. Madrid: Alianza Editorial, 1982

40

PRO, Juan. Inventario y extracción de los recursos: reclutamiento, recaudación y estadistica en la construcción del Estado nacional. In: MORAL, Joaquín del; PRO, Juan; SUÁREZ, Fernando. Estado y territorio en España, 1820-1930: la formación del paisaje nacional. Madrid: La Catarata - Universidad Rey Juan Carlos, 2007. P. 509-644.

41

50 aniversario de la creación de la Comisión de Estadística General del Reino. Madrid: Instituto Nacional de Estadistica, 2006

42

PRO, Juan. Estado, geometría y propiedad: Ios orígenes del catastro en España, 1715-1941. Madrid: Ministerio de Hacienda-Centro de Gestión Catastral y Cooperación Tributaria, 1992.

43

MURO, José Ignacio; NADAL, Francesc; URTEAGA, Luis. Geografía, estadística y catastro en España: 1856-1870. Barcelona: Serbal, 1996

44

URTEAGA, Luis; NADAL, Francesc. Las series del mapa topográfico de España a escala 1:50.000. Madrid: Centro Nacional de Información Geográfica, 2001. la penosa e insuficiente capacidad del transporte por carretera en la primera mitad del siglo. ${ }^{39}$ A ello habria que añadir la indudable unificación de mentalidades y culturas que favorecía el ferrocarril, haciendo circular de una región a otra, junto a todo tipo de mercancías, los periódicos y las personas; $y$, con ellos, las ideas.

Además de medidas con tanto valor simbólico como la unificación monetaria o como la construcción de redes centralizadas de carreteras, ferrocarriles, correos y telégrafos, en el terreno más propiamente cultural, los gobiernos impulsaron también las medidas que estaban a su alcance. En 1844 se fijó la ortografía oficial del castellano desde una institución semipública como era la Real Academia Española: el Estado se apropiaba de la lengua común, dándole de facto un cierto grado de oficialidad. Otro ejemplo serian las realizaciones en materia de estadistica y cartografía, dos funciones estatales que se pensaron como instrumentos de gobierno, pues debian proporcionar a la Administración información precisa sobre el territorio, su población y sus recursos, información imprescindible para tomar decisiones y ejecutarlas con eficacia. Pero, al mismo tiempo, las operaciones estadísticas y cartográficas suponían una exhibición del poder ya acumulado por el Estado y una apropiación simbólica del territorio y de todo lo que contenía por parte de las instituciones estatales, que lo definian, lo median, lo contaban y lo representaban gráficamente en cuadros y mapas. Esas instituciones estadisticas y cartográficas del Estado establecian las denominaciones oficiales - únicas válidas- tanto de las entidades de población como de los accidentes naturales. La apropiación era algo más que simbólica cuando cuadrillas de empleados públicos recorrian el territorio haciendo mediciones y recabando datos, e incluso dejaban marcas de esa toma de posesión estableciendo hitos topográficos y geodésicos con los símbolos del poder estatal. ${ }^{40}$ La primera institución de este tipo creada en España fue, en 1856, la Comisión de Estadística General del Reino (transformada luego en Junta de Estadistica y, ya en 1870, en Instituto Geográfico); desde esa institución se levantó el primer censo de población moderno en 1857, iniciando una serie regular que ha continuado hasta nuestros días. ${ }^{41}$ También se iniciaron en 1858 los trabajos del catastro, que había de someter a la vigilancia y medición del Estado la totalidad de las propiedades inmuebles del pais. ${ }^{42}$ En 1859 se aprobó la Ley de medición del territorio, que organizaba de forma sistemática las tareas de cartografía en todas sus escalas. ${ }^{43}$ Aunque con la lentitud habitual, finalmente se publicó en 1875 la primera hoja del Mapa Topográfico Nacional 1:50.000, que no por casualidad era la hoja central correspondiente a Madrid; y a partir de ahí continuaron los trabajos hasta cubrir con ese tipo de levantamiento topográfico la totalidad del territorio nacional ya durante el régimen de Franco. ${ }^{44}$

Más allá de las utilidades prácticas que para la Administración tiene disponer de un censo de población y de un mapa fiable del territorio, así como de otras estadísticas sectoriales que también se emprendieron en aquella época, cape pensar en el efecto simbólico sobre las mentalidades que tendrian tales trabajos. En especial la cartografía de Estado, que representaba el mapa nacional como un fenómeno natural e incontestable, expuesto visualmente en multitud de oficinas públicas junto a la bandera, y particularmente en las escuelas, donde se incrustaba en las mentes infantiles. Junto a la cartografía y la estadística, tampoco sería desdeñable el efecto de la creación de la red de observatorios meteorológicos en 1860: con ella, el Estado no solo se apropiaba de un importante sector de la actividad 
45

GIL Y ZÁRATE, Antonio. De la instrucción pública en España. Madrid: [s.n.], 1855. científica, recabando para sí la legitimidad adicional que la ciencia aportaba en la era del positivismo, sino que además proyectaba sobre los ciudadanos la más poderosa idea del Gobierno, capaz de predecir el tiempo que haria, cuando no de influir sobre el mismo.

En ese mismo empeño por moldear las mentalidades, la instrucción pública fue pensada desde el comienzo de la revolución como una necesidad para reeducar al pais en los principios liberales y para sacarlo de siglos de oscurantismo que habian mantenido a los españoles apartados del pensamiento y de la ciencia. Con la expresión obstáculos tradicionales se hacia referencia a la pertinaz resistencia de la Iglesia contra todo lo que significara investigación científica, libertad de pensamiento o educación en las ideas del siglo. De manera que se estimaba necesario un plan educativo impulsado y organizado por el Estado, que contrarrestara el monopolio tradicional que las instituciones eclesiásticas habian tenido en materia de educación. A este sistema se le llamó instrucción pública, y fue planteado con la mayor solemnidad de discurso como la gran palanca que debía modernizar el pais, sacarlo de la ignorancia y ponerlo a la altura de los países más avanzados de Europa. Quedó esbozado en el plan del Duque de Rivas en 1836; después se redefinió con el plan Pidal de 1845. Pero no fue hasta la Ley Moyano de 1857 cuando quedó definido un sistema estable de instrucción pública. ${ }^{45}$

Este sistema, que pervivió durante más de un siglo, hasta tiempos de Franco, era marcadamente centralizado, pues el Ministerio de Fomento (desglosado en un Ministerio específico de Instrucción Pública en 1901) definía no solo los niveles educativos y el curriculum de cada curso, sino también los contenidos de cada asignatura y hasta los manuales que debian utilizar estudiantes y profesores en todo el país. Como en tantos otros aspectos, sin embargo, este diseño educativo ambicioso, propio del Estado grande al que aspiraban idealmente muchos liberales de todos los partidos, se vio distorsionado en su aplicación práctica. Por un lado, la penuria económica en la que vivía el Estado, unida a la falta de una verdadera voluntad política para hacer de la educación una prioridad, llevó a establecer que fueran los municipios los que cargaran financieramente con los costes de la implantación de la instrucción pública; lo cual estableció fuertes desigualdades entre territorios en este asunto, pero en general mantuvo a las escuelas públicas en un estado de precariedad permanente. Por otro lado, los acuerdos con la Iglesia -reflejando tal vez convicciones de los propios dirigentes católicos del Estado- llevaron a permitir que las órdenes religiosas pudieran reimplantarse en España y desempeñar tareas educativas. Junto a las escuelas públicas, proverbialmente mal dotadas, reaparecieron asi escuelas y colegios católicos, que pronto tuvieron el control de la mayor parte de la educación, especialmente la que se especializaba en formar a los hijos de las familias de clase alta, de donde saldrian las elites dirigentes del Estado.

Habría otros terrenos a considerar como garantes de la estatalización de las mentes en la España del siglo XIX, y tal vez el servicio militar sería uno de ellos, tan importante o más que la escuela pública. El servicio militar, regulado en 1837 y de nuevo en 1856, sometía a los varones jóvenes a periodos de instrucción prolongados, pues el servicio activo era de cuatro años. Ofrecía, por tanto, la posibilidad de reeducar a los jóvenes con moldes estatistas, nacionalistas y -sin duda- militaristas; aunque el sistema de exenciones previsto, que permitía a las clases medias y altas redimir el servicio mediante pagos en dinero o mediante la contratación de un sustituto, le dio al servicio militar una dimensión clasista que lo hizo fuertemente impopular, 
SALES, Nuria. Sobre esclavos, reclutas y mercaderes de quintos. Barcelona: Ariel, 1974. FERNÁNDEZ VARGAS, Valentina. Sangre o dinero: el mito del ejercito nacional. Madrid: Alianza Editorial, 2004.

48

VEIGA, Xosé Ramón. El liberalismo conservador. Orden y libertad. In: ROMEO, María Cruz; SIERRA, María (coords.). La España liberal, 1833-1874. Historia de las culturas políticas en España y América Latina, II. Madrid-Zaragoza: Marcial Pons -Prensas de la Universidad de Zaragoza, 2014. P. 289-316. al tiempo que le restaba significación como mecanismo de inoculación del patriotismo o de creación de vínculos de solidaridad nacional. ${ }^{46}$

\section{Los modelos en competencia: imaginarios de Estado}

El Estado-nación, que condensa en sí todos los rasgos que caracterizan a la modernidad occidental, no se construyó al azar, pero tampoco siguiendo un plan preconcebido. No se construyó al azar, añadiendo, quitando o corrigiendo instituciones por unos o por otros, en función de circunstancias y necesidades inmediatas; ni en España ni en ningún otro país. De haber sido así, el resultado sería mucho más abigarrado e incoherente de lo que históricamente ha sido; y no se parecerian tanto entre sí los estados nacionales surgidos en diferentes paises. Las circunstancias y las necesidades desempeñaron, sin duda, un papel: limitaron el marco de acción de los constructores del Estado, haciendo inviables determinadas opciones y posibles otras. Pero dentro de esas condiciones de posibilidad hubo siempre más de una opción, y ahí fue donde actuaron los imaginarios de Estado que los diferentes grupos, partidos e individuos llevaban consigo.

Como queda de manifiesto en las páginas anteriores, las reformas uniformizadoras y centralizadoras se extendieron a lo largo de todo el siglo XIX; pero hubo un momento especialmente intenso de construcción de Estado en los años del reinado de Isabel II en que gobernó el Partido Moderado. De hecho, el modelo de Estado que pergeñaron los moderados en la década en que permanecieron en el poder de forma continuada (de 1844 a 1854) prolongó su influencia hasta mucho después, y se podría decir que fue la matriz básica del Estado español contemporáneo, sobre la cual solo pudieron introducir matices y perfeccionamientos parciales los gobiernos de otro signo que se sucedieron hasta la Constitución de 1978.

La visión ideal del Estado que albergaban los moderados era deudora del bonapartismo, más que de la Revolución francesa. Consistía en un régimen administrativo uniformizado, jerarquizado y centralizado, como garantía de eficacia al servicio de una concentración del poder en manos del Gobierno. Y era perfectamente coherente, por tanto, con unas posturas políticas que, dentro de las formas liberales, tendian al autoritarismo, la restricción de la participación política y el respeto a las prerrogativas de la Corona. En materia de principios, la conservación del orden la ponían siempre por encima de los demás valores políticos y sociales; 0 , por decirlo con los términos de Comte, preferian el orden al progreso. ${ }^{47}$

Este modelo de Estado era semejante, en muchos aspectos, al que había intentado implantar el Gobierno afrancesado de José Bonaparte durante la Guerra de la Independencia, aunque el patriotismo militante del partido moderado le impidiera admitir públicamente esta filiación (de hecho, algunos personajes relevantes en el diseño del nuevo Estado, como el mencionado Javier de Burgos, tenían un pasado afrancesado). No obstante, el imaginario de Estado de los moderados también tenía una filiación más estrictamente hispánica, que lo vinculaba al Antiguo Régimen: en el plano de las prácticas, los moderados llevaban hasta el nivel nacional las formas de gobierno político y económico de los pueblos que se habian desarrollado en el nivel local entre los siglos XVI y XVIII; en el plano de los imaginarios, los moderados eran los herederos del ideal del reformismo ilustrado que quedó interrumpido por la invasión francesa de 1808 y que nunca había llegado a 
48

OLIVÁN, Alejandro. De la administración pública con relación a España. Madrid: Boix, 1843.

49

PRO, Juan. Bravo Murillo: politica de orden en la España liberal. Madrid: Sintesis, 2006. realizarse plenamente. De lo que se trataba era de recobrar aquel impulso de racionalización burocrática y de centralización política y administrativa, separándolo de cualquier vinculación al absolutismo y añadiéndole las garantías jurídicas propias de un Estado de Derecho. Ese sueño de un Estado fuerte, que les permitiera intervenir eficazmente en todas las áreas de la vida social, quedó expresado nítidamente en escritos de los años cuarenta de los autores ya citados, y especialmente en un libro-programa de Alejandro Oliván de 1843, en el que expuso con detalle su modelo para cada ramo de la Administración pública, desde la estadistica hasta la policía, los ministerios, las provincias o los bosques. ${ }^{48}$

El modelo de Estado del Partido Moderado alcanzó su expresión más depurada y radical al final de la década moderada y por inspiración del ala derecha del partido, bajo la dirección de Bravo Murillo. A este jurista y político moderado se le deben importantes pasos en la construcción del Estado, como la uniformización de pesas y medidas, el arreglo de la deuda pública, la unidad de caja de la Administración, el sistema de contabilidad de la Hacienda Pública, la estructura radial de la red ferroviaria, el deslinde de competencias entre la Iglesia y el Estado por el Concordato de 1851 o el decreto que organizó el funcionariado en 1852 (vigente hasta 1914).49

Incluso el proyecto de reforma constitucional que lanzó Bravo Murillo en 1852, con un contenido claramente involucionista y autoritario, apuntaba en la misma dirección, de llevar hasta el extremo la concepción conservadora del Estado que tenían los moderados. Los proyectos de 1852 reducian la participación política, concentrando el poder en un ejecutivo fuerte, auxiliado por una administración densa, jerarquizada y eficaz. Aquel proyecto, que no salió adelante, era la plasmación perfecta del ideal bonapartista; $y$, de hecho, se inspiraba en el reciente golpe de Estado de Luis Napoleón Bonaparte y en la deriva autoritaria que inició Francia bajo su mando. El plan de Bravo Murillo, versión extrema del Estado grande de los moderados, pasaba por encima de los intereses de los notables locales, a los que habría hecho perder su autonomía política y su derecho de veto a la legislación estatal desde el Congreso; por eso no pudo salir adelante, y una extensa coalición de opositores de todo signo acabó apartándolo del poder y provocando la revolución de 1854 . Pero, como referente ideal resurgiría una y otra vez en tiempos posteriores este modelo de más administración y menos participación: no sólo en los últimos años del reinado de Isabel II (cuando este tipo de ideas volvieron a ser las oficiales del Partido Moderado), sino también en la dictadura de Primo de Rivera y hasta en ciertas formulaciones del franquismo (regímenes que compartieron la inclinación de Bravo Murillo hacia la tecnocracia y la legitimación por las obras públicas).

Lo cierto es que, al terminar la Década Moderada (1854) ya se habian puesto los cimientos del Estado contemporáneo en España; al terminar el reinado de Isabel II (1868), éste había quedado definido en sus rasgos esenciales. Y la Restauración borbónica de 1874 no hizo más que completar el proceso, de manera que hacia finales del siglo XIX ya existía en España un Estado nacional plenamente consolidado, bajo la fórmula de Estado-nación y con un notable efecto sobre su estructura de la dimensión imperial que por entonces se liquidaba con la pérdida de las últimas colonias en 1898. Eso no quita que aún se introdujeran algunos elementos nuevos a lo largo de las primeras décadas del siglo XX; pero en ese primer tercio del siglo la cuestión prioritaria no era ya la de construir un Estado y dotarle de capacidad de actuación, sino el conflicto por la reforma del Estado en una u otra dirección, 
para adaptarse a las necesidades de una época de movilización de masas.

En aquel modelo de Estado que se impuso había, como se ha señalado, una cierta influencia francesa, ligada a la concepción de la Administración pública y de su papel en la unificación de la nación y la construcción de un Estado unitario. Pero predominaban las raíces autóctonas. Por un lado, habia elementos que remitían a la tradición católica y al modelo de organización jerárquica que la Iglesia seguía poniendo en práctica todavía en el siglo XIX. También a la herencia de la Monarquía española del Antiguo Régimen, con la que había claros elementos de continuidad, visibles en la pervivencia de la forma monárquica del Estado bajo la dinastía de Borbón, pero también en la articulación territorial del poder, en la preeminencia de las entidades locales y en la lógica de gobierno de los pueblos. Por otro lado, estaba la mencionada incidencia del factor colonial, que devolvía su reflejo a la España metropolitana en forma de acumulación de capital y de recursos materiales y simbólicos de poder que acentuaban la dimensión autoritaria del Estado en construcción.

Los restantes modelos de Estado, que acompañaron y matizaron al de los moderados, son más difíciles de perfilar, porque corresponden a grupos que tuvieron menos oportunidades para desarrollar sus proyectos y ponerlos en práctica desde el poder. El primero sería el de los progresistas. El Partido Progresista fue una formación muy plural, cuyas divisiones internas impiden perfilar claramente si tenían un imaginario de Estado común. No obstante, el suyo podría caracterizarse como el modelo liberal propiamente dicho, sin los compromisos con el Antiguo Régimen a los que se ha aludido en el caso de los moderados. Pensaban en un Estado más liberal, en el sentido de tener un ejecutivo menos autoritario y una administración menos centralizada. Así, sus diversas corrientes coincidian en puntos netamente liberales, como los siguientes: someter al gobierno más estrechamente al control del parlamento y de un electorado más amplio; liberar a los ayuntamientos del control del Ministerio de la Gobernación, ampliando los márgenes de la autonomía municipal; reducir el intervencionismo del Estado en la economía (como hicieron cuando llegaron al poder en 1868).

Aparentemente, los progresistas pensaban en un tipo de Estado más pequeño y que pesara menos sobre las vidas de los ciudadanos. Por ejemplo, defendieron la liquidación del servicio militar obligatorio y su sustitución por un ejército profesional más reducido; aunque nunca llegaron a hacerlo realidad, y podemos dudar si formaba parte de una concepción del Estado o era un elemento táctico o propagandístico para atraerse las simpatías de unas clases populares castigadas por la desigualdad social de las "quintas". También mostraron menos tendencia al compromiso con el pasado y con los poderes de hecho procedentes del Antiguo Régimen, como la Corona, la Iglesia o las peculiaridades forales, todas ellas consideradas como obstáculos en el proyecto de Estado nacional de los progresistas. De hecho, fueron los progresistas los que impulsaron la desamortización de los bienes de la Iglesia y la reforma del clero entre 1835 y 1841.

No cabe duda de que los progresistas defendieron un tipo de Estado más participativo y representativo. No sólo defendieron la ampliación del derecho de voto y la hicieron realidad cuando alcanzaron el poder. También aumentaron la eficacia del control parlamentario sobre el gobierno. Defendieron el carácter representativo de los ayuntamientos, apartándolos en cierta medida de la injerencia del Gobierno. Y confiaron en la institución del jurado para la administración de justicia, y especialmente para hacer 
Una revisión general de la cultura politica progresista en la España del siglo XIX está recogida en SUÁREZ CORTINA, Manuel (ed.). La redención del pueblo: la cultura progresista en la España liberal. Santander: Universidad de Cantabria, 2006.
Como sugeria el libro de ARRESE, Julián de. Descentralizacion universal ó El Fuero Vascongado aplicado á todas las provincias: con un exámen comparativo de las instituciones vascongadas, suizas y americanas. Madrid: Librería de Victoriano Suárez, 1873. realidad ciertas libertades constitucionales, como la libertad de imprenta. Por fin, otra diferencia que se pueden señalar con respecto a los moderados es la influencia británica, muy presente en la cultura política de dirigentes progresistas como Juan Álvarez Mendizábal o Salustiano Olózaga. Eso no significa que no tuvieran una idea del Estado relacionada con el modelo francés, sino sólo que esa influencia fundamental la mitigaban con la comparación con el Reino Unido y la ocasional preferencia por instituciones y estructuras británicas. ${ }^{50}$

Donde sí había una opción claramente diferenciada, con respecto a la alternancia de matices entre progresistas y moderados, era en el carlismo, que les disputaba a ambos el control del territorio y la legitimidad politica. Como opción reaccionaria, el carlismo no consideró necesario hacer explícito su modelo político hasta fechas bastante avanzadas de su historia, cuando el mero regreso al pasado no entraba ya en lo posible. Sin embargo, dejaron muchos testimonios escritos de su visión del mundo, y el modelo institucional concreto que perseguian puede deducirse $d$ el análisis de la administración provisional que los carlistas erigieron en los territorios que controlaron durante las dos guerras civiles, especialmente en la segunda.

Evidentemente, en la propuesta carlista había un grado máximo de continuidad con el Antiguo Régimen, no matizado por la aceptación de ninguna de las conquistas de la revolución. Ese aprecio por el Antiguo Régimen se reflejaba en la propuesta de una Monarquía absolutista y un Estado confesional. Con tales premisas, resulta más que dudoso que la propuesta política del carlismo implicara la construcción de un Estado propiamente dicho: si el poder se seguía ejerciendo como servicio personal al monarca; si el monarca era absoluto y estaba, por tanto, desligado de la obligación de cumplir las leyes; y si el respeto a la posición de la Iglesia llevaba a no arrebatarle su independencia con respecto al poder político ni su capacidad para actuar sobre la vida social en amplios sectores de actividad (como la beneficencia, la sanidad, la educación, el registro civil, etc.)... el resultado se habria parecido más a una Monarquía de Antiguo Régimen que a un Estado nacional (o un Estado propiamente dicho, con el concepto que precisamos al inicio de esta sesión).

A esto se fue añadiendo, con un énfasis cada vez mayor, la idea de descentralización como alternativa al centralismo liberal. El carlismo se erigió en defensor de la diversidad regional y de los ordenamientos jurídicos tradicionales, llegando a hablar algunos de sus portavoces de una "Monarquía federal". En la práctica, esa defensa del pluralismo de las provincias se concretó en el modelo del régimen foral, tal como se practicaba en las Provincias Vascongadas y Navarra hasta 1840, sin que quedara nunca claro el grado de oportunismo de la propuesta, ni en qué medida pensaban hacerla extensiva a otros territorios. ${ }^{51}$ Parece que el tradicionalismo de los carlistas les llevaba más bien a pensar en un modelo de descentralización asimétrico e historicista, que nada tenía que ver con el federalismo, y que, una vez más, permite dudar del carácter estatal y nacional de la organización política resultante.

Aparte de los tres pilares básicos que forman el absolutismo, el confesionalismo y el foralismo, el imaginario político carlista venía caracterizado por rasgos como los siguientes: la restricción de la participación en todos los niveles, a fin de concentrar el poder en un ejecutivo autoritario; la existencia de una serie de organismos -consejos y asambleas- con funciones meramente consultivas, para auxiliar al rey y a su gobierno; el protagonismo 
MONTERO DÍAZ, Julio. El estado carlista: principios teóricos y práctica política (1872-1876). Madrid: Aportes XIX, 1992. de los municipios como células básicas, municipios poco representativos en su composición, y que estarían representados en las asambleas de la Monarquía orgánicamente, sin proporcionalidad con respecto a su número de habitantes; el rechazo a la división de poderes, manifiesto no sólo en la tendencia del ejecutivo regio a invadirlo todo, sino en extremos como el de reunir los alcaldes la función de jueces de primera instancia; la delegación de la mayor parte de las funciones administrativas en manos de los organismos territoriales constituidos, como eran las diputaciones en el caso de los territorios forales, $y_{1}$ a través de las diputaciones, en los ayuntamientos. Los carlistas no solían referirse a modelos extranjeros de manera tan abierta como los liberales; pero, si algún modelo tenían presente en sus proyectos de actualización de la Monarquía tradicional española, sería el modelo del Imperio Austriaco.

Se ha relacionado al "Estado carlista" con la dictadura de Franco, como consecuencia de que, al ser esa la época en que los carlistas llegaron a compartir de hecho el poder en España, se podría pensar que el régimen franquista fuera la realización histórica más cercana a aquellos postulados..$^{52}$ Pero las diferencias parecen demasiado evidentes como para que tal comparación resulte aceptable: no sólo el foralismo fue abandonado como postulado básico, sino que también fue obviado por completo el legitimismo dinástico. El único parecido real, que es la existencia de un ejecutivo autoritario y confesional, palidece ante la diferencia que supone el que el franquismo desarrollara un Estado en toda la extensión de la palabra, y que pusiera al servicio de su idea de Estado centralista y uniformizadora una administración densa e intervencionista a ultranza. Más que esta comparación poco plausible entre el proyecto cuasi estatal de los carlistas y el Estado hipertrofiado del franquismo, hay que reparar en los muchos elementos clave del ideario carlista que fueron incorporados en la construcción del Estado nacional por otros actores, como el Partido Moderado, en parte para atraer hacia el régimen a esta disidencia tradicionalista y en parte también por convicción de los propios dirigentes moderados, que llevaban sus ideas conservadoras hasta el límite con la satisfacción de saber que al hacerlo reforzaban las bases sociales de la monarquía y de su propio partido: la confesionalidad del Estado, el reforzamiento de las atribuciones políticas de la Corona, el reconocimiento parcial de los privilegios forales de las provincias vascas y Navarra, la limitación de la libertad de prensa (especialmente en asuntos que tocaran al dogma católico) y, en general, todas las tendencias autoritarias que impregnaron la construcción del Estado en los periodos de gobierno de moderados y conservadores, irian en esa dirección.

En el otro extremo del espectro político del reinado de Isabel II se situaba la opción de los demócratas, grupo escindido del Partido Progresista en 1849, y donde se situaban los primeros republicanos españoles. Los demócratas apenas tuvieron otro programa que una radicalización de los postulados progresistas, que acabaría llevándoles hasta el republicanismo: sufragio universal, hegemonía política del parlamento, fortalecimiento de las libertades individuales... Con respecto al modelo de Estado, la mayor parte de ellos se mantuvieron fieles a la forma monárquica tradicional, sin más que recortar las prerrogativas de la Corona hasta hacer de la monarquía constitucional una verdadera monarquía parlamentaria; incluso los que se decantaron por la República, frecuentemente pensaban en una mera sustitución de la figura del rey por la de un presidente electo en la jefatura del Estado. No así los federalistas, de quienes vino la innovación más relevante 
53

PEYROU, Florencia. Tribunos del pueblo: demócratas y republicanos durante el reinado de Isabel II. Madrid: Centro de Estudios Políticos y Constitucionales, 2008

54

DURÁN DE LA RÚA, Nelson. La Unión Liberal y la modernización de la España isabelina: una convivencia frustrada, 1854-1868. Madrid: Akal, 1979. en cuanto al modelo de Estado, pero que fueron muy minoritarios.

La idea de República federal, presente desde los años cuarenta del siglo XIX en corrientes marginales del partido demócrata suponía un modelo alternativo radicalmente nuevo, definido y coherente. Junto a ella venía la referencia a los Estados Unidos de América como modelo, exótica en el panorama español de la época, y que ganaría peso durante el sexenio revolucionario iniciado en 1868. La variante cantonalista, surgida de una aplicación a ultranza del principio federativo, vino a expresar la vitalidad de las identidades locales en la cultura política del país.

Al igual que los progresistas, los demócratas abogaron por la reducción y profesionalización del Ejército, pero manteniendo a la Milicia Nacional como fuerza popular de reserva. Entre las pocas novedades administrativas que plantearon destaca la de hacer coincidir todas las divisiones territoriales del pais con las provincias civiles, incluidas las diócesis eclesiásticas. Las restantes propuestas del programa demócrata parecen ser declaraciones de intenciones que apuntaban hacia un cierto electorado, como la insistencia en la prioridad de la instrucción primaria obligatoria y gratuita, la independencia del poder judicial, o la mejora de la estadística para garantizar un reparto equitativo de las contribuciones. ${ }^{53}$

Por último, en 1854 se formó la Unión Liberal, solución centrista surgida de la escisión de ala más avanzada del moderantismo (los puritanos), reforzada con elementos conservadores del Partido Progresista. Como no podía ser de otra manera, su modelo de Estado procedía de una amalgama de elementos moderados y progresistas, en busca de esa tercera vía, en la que destaca la actitud ecléctica, pragmática y oportunista. ${ }^{54}$

En definitiva, si se analiza la obra política y administrativa de los gobiernos de la Unión Liberal, lo que se encuentra es un avance significativo en la construcción material del Estado diseñado por los moderados, impulso facilitado por la bonanza económica que les tocó vivir y por la menor inclinación al compromiso con ideas y personas del Antiguo Régimen. Gracias a ello, el Estado de los unionistas avanzó significativamente en el desarrollo del ramo de Estadística, en la financiación de una política exterior más activa y agresiva, y en la actuación del sector público como dinamizador del crecimiento económico (mediante la construcción de obras públicas y una atención especial a las comunicaciones). Los elementos progresistas del ideario unionista fueron menos visibles: se limitaron a una discretísima descentralización municipal y a una lectura algo más generosa de las libertades individuales y la representación política.

La importancia de esta revisión del modelo moderado de Estado que hicieron los unionistas de 0'Donnell y Posada Herrera estriba en que suministró la base para el partido conservador de Antonio Cánovas del Castillo. Por tanto, el unionismo constituyó la fuente de inspiración fundamental para el régimen de la Restauración de 1874-1923, que habría de enmarcar la consolidación de un modelo de Estado básicamente definido durante el reinado de Isabel II. A ese modelo, Cánovas le añadiría muy poco más que el aprendizaje de los errores históricos del moderantismo y la admiración por el ejemplo británico.

Entre los elementos comunes de los cinco imaginarios de Estado principales que concurrieron en el reinado de Isabel II (moderados, progresistas, carlistas, demócratas y unionistas) resulta de especial importancia la preponderancia del localismo. Las identidades locales habian sido desde antiguo la base para la noción de naturaleza en los reinos de la Monarquía. El 
tránsito al régimen liberal se hizo mediante procesos revolucionarios que tuvieron una importante base local, demostrando que era ese ámbito el que concitaba las lealtades primordiales: la revolución la dirigieron juntas locales y provinciales, que sólo después de ver aseguradas sus reclamaciones básicas aceptaron ceder el poder a algún órgano de ámbito nacional.

Aquel localismo original quedó impreso a fuego en el Estado contemporáneo y en todos los programas que pugnaban por orientar su construcción, aunque esa presencia se manifestara de maneras diversas, como ya hemos visto: los moderados, que soñaban con un Estado grande basado en una administración centralista, uniforme y eficaz, y que mantuvieron esa ficción jurídica, se tuvieron que contentar en la práctica con una confederación de oligarquias locales y provinciales que negociaban con el poder central su colaboración en las tareas del Estado; los progresistas hicieron de la descentralización una de sus banderas políticas más sonadas, proponiendo la autonomía municipal como panacea de la libertad moderna; los carlistas pretendian una Monarquía en la que todo el poder se concentraría en la Corona, pero toda la administración quedaría delegada en los municipios y provincias; los demócratas, que cultivaban el ideal descentralizador de los progresistas, engendraron en su seno un republicanismo federal y una insurgencia cantonalista (1873-74) que llevaron la soberanía local hasta el extremo; y los unionistas se las ingeniaron para combinar el municipalismo doctrinal de los progresistas con el clientelismo descentralizador que practicaban tanto éstos como los moderados, dando lugar al caciquismo de los comienzos de la Restauración, paraíso de los oligarcas locales.

Ese importante elemento común no significa que todos los programas remitieran a un mismo modelo. De hecho, hubo entre ellos una relación dialéctica: los moderados hegemonizaron el proceso de construcción del Estado, haciendo que éste llevara la impronta de su origen moderado hasta tiempos recientes. El Estado que construyeron intentaba ser un punto de encuentro entre las propuestas liberales (reflejadas en el modelo progresista) y la resistencia absolutista (identificada con el modelo carlista): los progresistas consiguieron corregir en algunos puntos el entramado estatal que estaban construyendo los moderados, en los breves periodos en que consiguieron acceder al poder; y tanto los carlistas como los progresistas influyeron desde fuera, condicionando las opciones de los moderados a la búsqueda de los modelos que pudieran recabar mayor consenso.

Los unionistas se limitaron a actualizar el Estado de los moderados, adaptándolo a nuevos tiempos y dándole mayor eficacia; sin más que eso, lo plasmaron en el régimen de la Restauración y permitieron que durara hasta 1923. La estabilidad política de la Restauración proporcionó las condiciones necesarias para hacer realidad el Estado grande concebido por los moderados, superando gradualmente los obstáculos que habian hecho desistir de su materialización durante el reinado de Isabel II; se desarrolló la burocracia administrativa, se centralizó el poder y se completaron las redes de comunicación y transporte que aseguraban el control gubernamental del territorio.

Todo ello fue un proceso gradual que, partiendo de las modestas realizaciones del reinado de Isabel II (1833-1868) y del sexenio revolucionario (1868-1874), acabó con el aislamiento de las comunidades locales y con el poder de hecho de sus oligarquias, introduciéndolas en un escenario político común de ámbito nacional. Esa transformación se completó hacia finales del siglo XIX, momento en que arreciaron las críticas contra el "centralismo" (como las reflejadas en los escritos regionalistas y regeneracionistas). En los 
años noventa se produjeron toda una serie de reacciones nacionalistas contra este control gubernamental, sobre todo en Cataluña (Bases de Manresa, 1892), País Vasco (creación del Euskaldun Batzokija por Sabino Arana, 1894) y Cuba (Grito de Baire, 1895): su simultaneidad y su pujanza se debieron a la percepción de una acción intensa del Estado sobre la totalidad del territorio, que empezaba a convertir en realidad el proyecto liberal del Estado-nación en España.

Hay que advertir que ese tramo final de la construcción del Estado no resultó de una plasmación automática del modelo moderado, sino de una actualización del mismo por los conservadores de Cánovas. El Partido Conservador, siguiendo el planteamiento de los unionistas, accedió a la alternancia política con el Partido Liberal que lideraba Sagasta y a asociar a éste en la tarea de construir un Estado nacional de consenso. Durante la Restauración, por tanto, se incorporaron a la construcción del Estado los herederos del progresismo y de una democracia templada, amalgamados en el Partido Liberal, que realizó importantes aportaciones reformistas en la fase final de la construcción del Estado, a partir de 1881: libertad de cátedra (1881), sufragio universal (1882-90), libertad de imprenta, Academia General Militar, Comisión de Reformas Sociales (1883), cuerpo de Abogados del Estado, Academia de Sargentos, Cámaras de Comercio (1886), libertad de asociación (1887), juicio por jurados (1888), Ley de lo contencioso administrativo (1888, reformada en 1894), cuerpo de Correos, Ley del Ejército, Código Civil (1889), regiones militares (1893), liquidación del imperio colonial (1898), Ministerio de Instrucción Pública (1901)... Los demócratas avanzados y republicanos, en cambio, se siguieron manteniendo críticos con todo este constructo, sin que su breve y agitado paso por el poder durante el sexenio revolucionario les permitiera poner en práctica una alternativa, cuya visibilidad se demoraria, pues, hasta 1931.

Terminamos este recorrido esquemático por los imaginarios de Estado presentes durante la construcción del Estado nacional en España sin ningún ánimo exhaustivo, sin más intención que la de esbozar un proceso histórico con el cual mostrar las posibilidades que ofrece una perspectiva cultural sobre dicho proceso. Perspectiva y posibilidades que aún están en gran medida por explorar.

\section{Referencias Bibliográficas}

150 aniversario de la creación de la Comisión de Estadística General del Reino. Madrid: Instituto Nacional de Estadística, 2006.

ARRESE, Julián de. Descentralizacion universal ó El Fuero Vascongado aplicado á todas las provincias: con un exámen comparativo de las instituciones vascongadas, suizas y americanas. Madrid: Librería de Victoriano Suárez, 1873.

ARTOLA, Miguel. El modelo constitucional español del siglo XIX. Madrid: Fundación Juan March, 1979.

- La hacienda del siglo XIX: progresistas y moderados. Madrid: Alianza Editorial, 1986. - La monarquía de España. Madrid: Alianza Editorial, 1999.

- Los orígenes de la España contemporánea. Madrid: Instituto de Estudios Políticos, 1959.

ARTOLA, Miguel (ed.). Los ferrocarriles en España, 1844-1943, I: El Estado y los ferrocarriles. Madrid: Banco de España, 1978.

BONNEY, Richard (ed.). Economic systems and state finance. The Origins of the 
Modern State in Europe, 13th-18th centuries. Oxford: Oxford University Press, 1995.

BOURDIEU, Pierre. Sobre el estado: cursos en el Collège de France (1989-1992). Barcelona: Anagrama, 2014.

BURGUEÑO, Jesús. Geografía política de la España constitucional: La división provincial. Madrid: Centro de Estudios Constitucionales, 1996.

CAJAL VALERO, Arturo. El gobernador civil y el estado centralizado del siglo XIX. INAP, 1999.

CASELLI, Elisa (ed.) Justicias, agentes y jurisdicciones. De la Monarquía Hispánica a los Estados Nacionales (España y América, siglos XVI-XIX). Madrid: Fondo de Cultura Económica, En prensa.

CARDOSO, José Luis; LAINS, Pedro (eds.). Paying for the liberal state. The rise of the public finance in nineteenth-century Europe. Cambridge: Cambridge University Press, 2010.

CASTRO, Concepción de. La revolución liberal y los municipios españoles (1812-1868). Madrid: Alianza Editorial, 1979.

CENTENO, Miguel Ángel. Blood and Debt. War and the Nation-State in Latin America. University Park : Pennsylvania State University Press, 2002.

COMín, Francisco (ed.). 150 años de historia de los ferrocarriles españoles. Madrid: Fundación de los Ferrocarriles Españoles, 1998.

COMíN, Francisco; VALLEJO, Rafael. Alejandro Mon y Menéndez (1801-1882): pensamiento y reforma de la Hacienda. Madrid: Instituto de Estudios Fiscales, 2002.

CONTENTE, Claudia (ed.). Justicia, violencia y construcción estatal. Illes $i$ imperis, n. 15, p.7-193, 2013.

CORRIGAN, Philip; SAYER, Derek. The great arch: English state formation as cultural revolution. Oxford: Blackwell, 1985.

DURÁN DE LA RUA, Nelson. La Unión Liberal y la modernización de la España isabelina: una convivencia frustrada, 1854-1868. Madrid: Akal, 1979.

ESTAPÉ, Fabián. La reforma tributaria de 1845: Estudio preliminar y consideración de sus precedentes inmediatos. Madrid: Instituto de Estudios Fiscales, 1971.

ETCHECHURY BARRERA, Mario. Hijos de Mercurio, esclavos de Marte. Mercaderes y servidores del Estado en una frontera sud-atlántica: Montevideo, 1806-1860. Rosario, Argentina: Prohistoria, En prensa.

ETZIONI, Amitai. A self-restrained approach to Nation Building by foreign powers. Foreign Affairs, n. 80-1, p. 1-17, 2004.

EVANS Peter B.; RUESCHEMEYER, Dietrich; SKOCPOL, Theda. Bringing the State Back In. Cambridge: Cambridge University Press, 1985.

FERNÁNDEZ VARGAS, Valentina. Sangre o dinero: el mito del ejercito nacional. Madrid: Alianza Editorial, 2004.

FONTANA, Josep. La revolución liberal: política y hacienda en 1833-1845. Madrid]: Instituto de Estudios Fiscales, 1977.

FRADERA, Josep Maria. Colonias para después de un imperio. Barcelona: Bellaterra, 2004.

FUENTES QUINTANA, Enrique. Las reformas tributarias en España: teoría, historia y propuestas. Barcelona: Crítica, 1990.

FUKUYAMA, Francis. State-building: Governance and World Order in the 21st Century. Ithaca, New York: Cornell University Press, 2004.

GARAVAGLIA, Juan Carlos. La disputa por la construcción nacional argentina. Buenos Aires, la Confederación y las provincias, 1850-1865. Buenos Aires: Prometeo, En prensa. 
(ed.). Recaudar y reconstruir el Estado. I/les $i$ imperis, n. 13, p. 7-213, 2010.

GARAVAGLIA, Juan Carlos; GAUTRAEU, Pierre (eds.). Mensurar la tierra, controlar el territorio: América Latina, siglos XVIII-XIX. Rosario, Argentina: Prohistoria Ediciones, 2011.

GARAVAGLIA, Juan Carlos; LAMOUROUX, Christian; BRADDICK, Michael J. (eds.). Serve the Power(s), Serve the State. America and Eurasia. Newcastle: Cambridge Scholars, En prensa.

GARAVAGLIA, Juan Carlos; PRO, Juan (eds.). Latin American Bureaucracy and the State Building Process (1780-1860). Newcastle: Cambridge Scholars, 2013.

GARAVAGLIA, Juan Carlos; PRO, Juan; ZIMMERMANN, Eduardo (eds.). Las fuerzas de guerra en la construcción del Estado: América Latina. Rosario: Prohistoria, 2012.

GAY ARMENTEROS, Juan C. Política y administración en Javier de Burgos. Granada: Centro de Estudios Municipales y de Cooperación Interprovincial, 1993.

GIL Y ZÁRATE, Antonio. De la instrucción pública en España. Madrid: [s.n.], 1855.

GÓMEZ MENDOZA, Antonio. Ferrocarriles y cambio económico en España, 1855-1913: un enfoque de nueva historia económica. Madrid: Alianza Editorial, 1982.

HERZOG, Tamar. Vecinos y extranjeros: hacerse español en la Edad Moderna. Madrid: Alianza Editorial, 2006.

JOURNEAU, Brigitte. Eglise et état en Espagne au XIXe siècle: les enjeux $d u$ concordat de 1851. Villeneuve d'Ascq: Presses Universitaires du Septentrion, 2002.

LÓPEZ-ALVES, Fernando. State formation and democracy in Latin America, 1810-1900. Durham: Duke University Press, 2000.

LÓPEZ BEJARANO, Pilar. Un Estado a crédito: Deudas y configuración estatal de la Nueva Granada en la primera mitad del siglo XIX. Bogotá: Pontificia Universidad Javeriana, 2015.

LÓPEZ GARRIDO, Diego. La Guardia Civil y los orígenes del estado centralista. Barcelona: Crítica, 1982.

LÓPEZ TAVERNE, Elvira. El proceso de construcción estatal en Chile: hacienda pública y burocracia (1817-1860). Santiago de Chile: Dibam - Centro de Investigaciones Diego Barros Arana, 2014.

LORENTE, Marta; PORTILLO, José María (eds.). El momento gaditano: la constitución en el orbe hispánico (1808-1826). Madrid: Congreso de los Diputados, 2011.

MADRAZO, Santos. El sistema de comunicaciones en España, 1750-1850. Madrid: Colegio de Ingenieros de Caminos, 1984.

MANN, Michael. Las fuentes del poder social, Il: el desarrollo de las clases y los estados nacionales, 1760-1914. Madrid: Alianza Editorial, 1993.

MARTÍNEZ DORADO, Gloria. La formación del Estado y la acción colectiva en España: 1808-1845. Historia social, n. 15, p. 101-118, 1993.

MARTORELL, Miguel. Historia de la peseta: la España contemporánea a través de su moneda. Barcelona: Planeta, 2002.

McNEILL, William. La búsqueda del poder. Tecnología, fuerzas armadas y sociedad desde el 1000 d.C. Madrid: Siglo XXI, 1988.

MEYER, John W.; BOLI, John; THOMAS, George M.; RAMÍREZ, Francisco 0. World society and the nation State. American Journal of Sociology, n. 103, p. 144-181, 1997. 
MONTERO DÍAZ, Julio. El estado carlista: principios teóricos y práctica politica (1872-1876). Madrid: Aportes XIX, 1992.

MORAL, Joaquín del; PRO, Juan; SUÁREZ, Fernando. Estado y territorio en España, 1820-1930: la formación del paisaje nacional. Madrid: La Catarata - Universidad Rey Juan Carlos, 2008.

MURO, José Ignacio; NADAL, Francesc; URTEAGA, Luis. Geografía, estadística y catastro en España: 1856-1870. Barcelona: Serbal, 1996.

OLIVÁN, Alejandro. De la administracion pública con relación a España. Madrid: Boix, 1843.

ORDUÑA REBOLLO, Enrique. Historia del Estado español. Madrid: Marcial Pons - Fundación Alfonso Martín Escudero, 2015.

PÉREZ LEDESMA, Manuel; SIERRA, Maria (eds.). Culturas políticas: teoría e historia. Zaragoza: Institución Fernando el Católico, 2010.

PEYROU, Florencia. Tribunos del pueblo: demócratas y republicanos durante el reinado de Isabel II. Madrid: Centro de Estudios Políticos y Constitucionales, 2008.

POGGI, Gianfranco. El desarrollo del Estado moderno: una introducción sociológica. Buenos Aires, Universidad Nacional de Quilmes, 1997.

PRO, Juan. Bravo Murillo: política de orden en la España liberal. Madrid: Sintesis, 2006.

. El Estatuto Real y la Constitución de 1837. Madrid: lustel, 2010.

. Estado, geometría y propiedad: los orígenes del catastro en España, 1715-1941. Madrid: Ministerio de Hacienda - Centro de Gestión Catastral y Cooperación Tributaria, 1992.

. Inventario y extracción de los recursos: reclutamiento, recaudación y estadística en la construcción del Estado nacional. In: MORAL, Joaquín del; PRO, Juan; SUÁREZ, Fernando. Estado y territorio en España, 18201930: la formación del paisaje nacional, 509-644. Madrid: La Catarata - Universidad Rey Juan Carlos, 2007.

PUELL DE LA VILLA, Fernando. Historia del ejército en España. Madrid: Alianza Editorial, 2000.

REDDY, William M. The Navigation of Feeling: A Framework for the History of Emotions. Cambridge-New York: Cambridge University Press, 2001.

RíOS, Evangelina de los. Una recaudación depurada de toda costumbre viciosa. Santa Fe, 1852-1873. Rosario, Argentina: Prohistoria, En prensa.

RODRÍGUEZ SOLANO, Pablo. Desconcierto, incertidumbre y hacienda pública: la construcción de Estado de Costa Rica (1821-1859). San José de Costa Rica: Universidad de Costa Rica, En prensa.

ROSANVALLON, Pierre. Por una historia conceptual de lo político. Madrid: Fondo de Cultura Económica, 2006.

SALES, Nuria. Sobre esclavos, reclutas y mercaderes de quintos. Barcelona: Ariel, 1974.

STEINMETZ, George (ed.). State/Culture. State Formation after the Cultural Turn. Ithaca, New York: Cornell University Press, 1999.

SUÁREZ CORTINA, Manuel (ed.). La redención del pueblo: la cultura progresista en la España liberal. Santander: Universidad de Cantabria, 2006.

TEDDE DE LORCA, Pedro. Los primeros ciento cincuenta años del Banco de España (1782-1931). In: MARTíN ACEÑA, Pablo; TITOS MARTíNEZ, Manuel (eds.). El sistema financiero en España: una sintesis histórica. Granada: Universidad de Granada, 1999. P. 53-82

TILLY, Charles. Coerción, capital y los estados europeos, 990-1990. Madrid: Alianza Editorial, 1992. 
(ed.). The Formation of National States in Western Europe. Princeton: Princeton University Press, 1975.

TORENO, Conde de (QUEIPO DE LLANO, José Maria). Historia del levantamiento, guerra y revolución de España. París: Librería Europea de Baudry, 1838.

Tratado de paz y amistad, celebrado entre España y la República Mejicana en 28 de diciembre de 1836. S.I.: S.n., 1838.

URTEAGA, Luis; NADAL, Francesc. Las series del mapa topográfico de España a escala 1:50.000. Madrid: Centro Nacional de Información Geográfica, 2001.

VEIGA, Xosé Ramón. "El liberalismo conservador. Orden y libertad». In: ROMEO, María Cruz; SIERRA, María (coords.). La España liberal, 18331874, 289-316. Historia de las culturas políticas en España y América Latina, Il. Madrid-Zaragoza: Marcial Pons - Prensas de la Universidad de Zaragoza, 2014. 